\title{
Article
}

\section{The Contractarian Basis of the Law of Trusts}

\author{
John H. Langbein ${ }^{\dagger}$
}

\author{
CONTENTS
}

I. INTRODUCTION . . . . . . . . . . . . . . . . 627

II. From Conveyance to MANAgement: The Historical

TRANSFORMATION OF THE TRUST . . . . . . . . . . 632

A. The Early Trust as a Means of Conveyance ......... 632

B. Why Early Trust Law De-emphasized Contract ........ 634

1. Failings of Covenant .................6634

2. Hostility to Assignment ................6635

3. The Role of Procedure ................ 635

4. Tracking the Common Law Estates ............ 636

5. Testamentary Trusts .................66 636

C. The Appearance of the Management Trust . . . . . . . 637

1. Financial Assets ................... 638

2. Institutional Trusteeship ............... 638

3. Safeguard: From Disempowerment to

Fiduciary Obligation ................6 640

III. PROBING THE OBJECTIONS TO CONTRACTARIAN ANALYSIS OF THE

MODERN TRUST . . . . . . . . . . . . . . . . . . . . 643

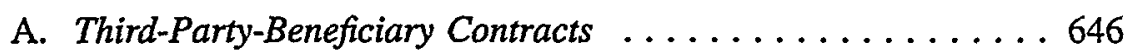

B. Implications of Equitable Tracing . . . . . . . . . . . 647

C. The Effect of Fusion on Trust Enforcement .......... 648

t Chancellor Kent Professor of Law and Legal History, Yale University. I am grateful for suggestions from Bruce Ackerman, Mark Ascher, Ian Ayres, Elias Clark, Richard Craswell, Jesse Dukeminier, Richard Epstein, Daniel Fischel, Lawrence Friedman, Mary Ann Glendon, Edward C. Halbach, Jro, Henry Hansmann, Richard Helmholz, David Johnston, Gareth Jones, Edmund Kitch, Alvin Klevorick, Bruce Mann, Thomas Roberts, Roberta Romano, Alan Schwartz, John Simon, Peter Stein, Lawrence Waggoner, and Richard Wellman. 
IV. THE FunCTIONAL CORRESPONDENCE OF TRUST AND CONTRACT . 650

A. Converging Trends in Contract and Trust Law .......... 652

1. Specific Performance .................6 653

2. Relational Contracting ................6653

3. Good Faith ...................... 654

B. Trust Fiduciary Law ................... 655

1. The Duties of Loyalty and Prudence ............ 655

2. The Contractarian Basis of Fiduciary Law ......... 657

C. Trust as a Standardized Contract ............. 660

1. Management Regime ..................660 660

2. Regime for Multiple and Successive Interests . . . . . . 661

3. Procedural Regime ................. 662

4. Statutory Trusts $\ldots \ldots \ldots \ldots \ldots \ldots \ldots \ldots \ldots 6 . \ldots \ldots 6$

D. Altering Outcomes ................... 663

1. Standing: Settlor Enforcement .............664 664

2. Embedded Conflicts of Interest ............. 665

E. Trustee Insolvency . . . . . . . . . . . . . 667

V. LESSONS FROM NONTRUST LEGAL SYSTEMS $\ldots \ldots \ldots \ldots \ldots 69$

VI. Conclusion $\ldots \ldots \ldots \ldots \ldots \ldots \ldots \ldots \ldots \ldots \ldots \ldots \ldots$

APPENDIX: THE DEClaRATION OF TRUST $\ldots \ldots \ldots \ldots \ldots \ldots \ldots 72$

A. The Declaration of Trust as Nonprobate Will ......... 673

B. The Declaration of Trust as Curative for Failed Inter Vivos Gift . . . . . . . . . . . . . . . . 673

C. The Declaration of Trust as Conduit to Three-Party Trust . . . 674 


\section{INTRODUCTION}

We are accustomed to think of the trust as a branch of property law. The Restatement (Second) of Trusts defines the trust as "a fiduciary relationship with respect to property," and the codes ${ }^{2}$ and treatises ${ }^{3}$ say similar things. This way of speaking about the trust omits an important dimension.

The contractarian claim. In truth, the trust is a deal, a bargain about how the trust assets are to be managed and distributed. To be sure, the trust originates exactly where convention says it does, with property. The Restatement says, "A trust cannot be created unless there is trust property." The owner, called the settlor, transfers the trust property to an intermediary, the trustee, to hold it for the beneficiaries. We treat the trustee as the new owner for the purpose of managing the property, while the trust deal strips the trustee of the benefits of ownership.

The distinguishing feature of the trust is not the background event, not the transfer of property to the trustee, but the trust deal that defines the powers and responsibilities of the trustee in managing the property. Sometimes the trust deal also confers significant discretion upon the trustee over dispositive provisions, that is, in allocating the beneficial interests among the beneficiaries. The settlor and the trustee may express their deal in detailed terms drafted for the particular trust, or they may be content to adopt the default rules of trust law. Either way, the deal between settlor and trustee is functionally indistinguishable from the modern third-party-beneficiary contract. Trusts are contracts.

Trust without contract. The contractarian account, presupposing a separate trustee, does not embrace the declaration of trust, which is a mode of trust creation that allows the transferor of property simply to declare himself or herself trustee for the transferee. ${ }^{5}$ This two-party trust lacks a separate trustee. The settlor cannot contract with himself or herself, and accordingly, we see that trust can arise without contract, without the characteristic deal between settlor and third-party trustee. Because the declaration of trust dispenses with what is normally the most desirable attribute of the trust, that is, the ability to

1. RESTATEMENT (SECOND) OF TRUSTS $\$ 2$ (1959). The full definition is quite convoluted: "a fiduciary relationship with respect to property, subjecting the person by whom the title to the property is held to equitable duties to deal with the property for the benefit of another person, which arises as a result of a manifestation of an intention to create it." This formulation postpones to the final phrase its imperfect acknowledgement of the central dynamic of the trust, the deal between the settlor and the trustee, which in my view "manifest[s]" not only the settlor's "intention to create it" but also the trustee's intention to perform it.

2. See, e.g., TEX. Prop. CODE ANN. $\$ 111.004(4)$ (West 1984) (Texas Trust Code).

3. See, e.g., 1 AUSTIN W. SCOTT \& WILLIAM F. FRATCHER, THE LAW OF TRUSTS $\$ \$ 2.3-2.6$, at $40-48$ (4th ed. 1987-89) [hereinafter SCOTT \& FRATCHER, TRUSTS].

4. RESTATEMENT (SECOND) OF TRUSTS $\$ 74$ (1959).

5. "A trust may be created by ... a declaration by the owner of property that he holds it as trustee for another person ...." Id. $\$ 17(a)$. 
have a third party manage the trust property, the declaration of trust plays a relatively peripheral role in modern practice. In order not to interrupt the main theme of this Article, I discuss the declaration of trust in an appendix. I explain that the declaration sometimes serves as a way station to the creation of a true third-party trust, and that in other settings the declaration turns out to be a doctrinal ruse for validating transfers that are not in function trusts.

The contractarian theme. This Article sets forth the grounds for understanding the conventional three-party trust as a prevailingly contractarian institution. More is at stake in this choice between contract and property formulations of the trust than mere labelling. In Part IV of this Article, I explain why the law of fiduciary administration, which is the centerpiece of the modern trust, is overwhelmingly contractarian. Especially in conflict-of-interest cases, greater attention to the contractarian character of the trust would improve outcomes. ${ }^{6}$

Sensitivity to the contractarian character of the trust can be traced to Maitland's celebrated lectures on Equity, ${ }^{7}$ published posthumously in 1909. Even in the late fourteenth century, observed Maitland, when the English Chancellor first began to enforce the trust, the trust "generally ha[d] its origin in something that we can not but call an agreement." "[The] trust was originally regarded as an obligation, in point of fact a contract though not usually so called." F.H. Lawson, writing in 1953 in one of the central works of modern comparative law, pointed out that "the three-cornered relation of settlor, trustee, and [beneficiary] . . . is easily explained in the modern law in terms of a contract for the benefit of a third party."10

Our black letter law has resisted the insight that trusts are contracts. The second Restatement of 1959, carrying forward the language of the first Restatement of $1935,{ }^{11}$ declares: "The creation of a trust is conceived of as a conveyance of the beneficial interest in the trust property rather than as a contract." 12

This Article proceeds under four parts: history, doctrine, function, and comparison.

History. There was always a component of contract in the trust relationship, but profound changes in the character and function of the trust from the second half of the nineteenth century onward have intensified the

6. See infra text accompanying notes 205-14.

7. FREDERIC W. MAITLAND, EQUITY: A COURSE OF LECTURES (John Brunyate rev. ed., 2d ed. 1936) (A.H. Chaytor \& W.J. Whittaker eds., 1st ed. 1909) (Maitland died in 1906.).

8. Id. at 28; see also id. at 29 ("[T]he Chancellor begins to enforce a personal right . . . which in truth is a contractual right, a right created by a promise.").

9. Id. at 110 .

10. F.H. LAwSON, A Common Lawyer Looks at the Civil Law 200 (1953).

11. RESTATEMENT (FIRST) OF TRUSTS $\S 197 \mathrm{cmt}$. b (1935).

12. Restatement (SECOND) OF TRUSTS $\$ 197 \mathrm{cmt}$. b (1959). Further, "Although the trustee by accepting the office of trustee subjects himself to the duties of administration, his duties are not contractual in nature." Id. $\$ 169 \mathrm{cmt}$. c; $c f$. id. $\$ \$ 130,131$. 
contractarian basis of the trust. The trust originated as a conveyancing device for holding real property, often ancestral land. The modern trust has become a management regime for a portfolio of financial assets.

Part II of the Article reviews the central elements in this historical transformation of the trust, changes affecting (1) the nature of wealth, as financial assets displaced family land as the typical trust property; (2) the management responsibilities of trustees, who ceased being bare stakeholders of realty and became active portfolio managers; (3) the personality of trustees, as gentlemen stakeholders gave way to institutional fiduciaries; and (4) the locus of safeguard for beneficiaries within trust law, as fiduciary law came to replace the former reliance upon restricting trustees' powers.

Doctrine. Part III examines concerns that have been voiced against the contractarian account of the trust in doctrinal discourse: (1) the refusal of English law to recognize the third-party-beneficiary contract; (2) the argument that equitable tracing as practiced in the law of trusts precludes the contractarian account; and (3) fears based on the fusion of law and equity. I show that these supposed objections to the contractarian view of the trust are unpersuasive.

Function. Part IV of the Article develops the intrinsic functional correspondence between contract and trust. The bedrock elements of contract are consensual formation and consensual terms. Trust displays both. I follow for trust the insights of the law-and-economics literature, which has emphasized the contractarian basis of fiduciary duties in modern corporation law. I concentrate on the two central duties of trust fiduciary law, loyalty and prudence. My theme is that, despite decades of pulpit-thumping rhetoric about the sanctity of fiduciary obligations, fiduciary duties in trust law are unambiguously contractarian. The rules of trust fiduciary law mean to capture the likely understanding of the parties to the trust deal, which is why both the duty of loyalty and the duty of prudence yield to the more particularized intentions that the parties may choose to express or imply in their trust deal. I depict the default regime of trust law as a type of standardized contract, and I point to some instances in which the contractarian perspective should improve outcomes in trust law.

Comparative law. I conclude the Article, in Part V, by casting a short glance at European law. The Continental legal tradition did not develop the trust. Comparative lawyers understand that the civil law systems achieve mostly by means of contract what the Anglo-American systems do through the trust device-another important indication of how close the trust lies to contract in function. Civil law systems act on this insight in conflict-of-laws cases. When a nontrust jurisdiction confronts an attempted trust, the standard analysis is to assimilate the trust to the contract law of the nontrust jurisdiction. 
Beyond trusts. This Article draws upon bodies of scholarly literature and supporting legal authorities-historical, doctrinal, economic, and comparative-that have developed in substantial isolation from each other. In emphasizing a contractarian view of the trust, the Article falls within an intellectual movement broader than trust law. Contract has become the dominant doctrinal current in modern American law. In fields ranging from corporations ${ }^{13}$ and partnership, ${ }^{14}$ to landlord and tenant, ${ }^{15}$ to servitudes, ${ }^{16}$ to the law of marriage ${ }^{17}$ scholars have come to understand our legal rules as resting mainly on imputed bargains that are susceptible to alteration by actual bargains. ${ }^{18}$

It is not my purpose to fold the law of trusts into the law of contract. Like other legal institutions that have been deeply influenced by modern contractarian analysis, such as the corporation or the marriage, the trust has an institutional integrity and convenience that fully justifies its independence. My purpose is simply to show that contractarian analysis illumines, and at times helps us improve upon, what we do with the trust.

Exclusions. This Article is devoted to the gratuitous private trust, our characteristic device for conditioned wealth transfer within the family. The Article excludes commercial trusts. The flexibility of the trust as a regime for creating and managing multiple interests in assets has encouraged transaction planners to use the trust in a wide variety of commercial settings. ${ }^{19}$ For

13. See Frank H. EASTERBROOK \& DANIEL R. Fischel, THE ECONOMIC STRUCTURE OF CoRporate LAW (1991); Henry N. Butler \& Larry E. Ribstein, Opting Out of Fiduciary Duties: A Response to the AntiContractarians, 65 WASH. L. REV. 1 (1990).

14. The recent revisions to the Uniform Partnership Act greatly augment the sphere for contract to defeat the default regime, including the fiduciary duties of loyalty and good faith, subject to essentially procedural requirements of precise drafting and to an unconscionability check on contract terms that are "manifestly unreasonable." REVISED UNIF. PARTNERSHIP ACT \$§ 103, 404, 6 U.L.A. 288, 313 (1994).

15. See Mary Ann Glendon, The Transformation of American Landlord-Tenant Law, 23 B.C. L. REV. 503, 503-04 (1982); see also Edward Chase, The Property-Contract Theme in Landlord and Tenant Law: A Critical Commentary on Schoshinski's American Law of Landlord and Tenant, 13 RUTGERS L.J. 189 (1982).

16. See RestatemENT (THIRD) OF PROPERTY: SeRvitudes $\$ 2.16 \mathrm{cmt}$. b (Tentative Draft No. 3, 1993); Richard A. Epstein, Notice and Freedom of Contract in the Law of Servitudes, 55 S. CAL. L. REv. 1353 (1982). For citations to the literature on condominium and homeowner associations as consensual regimes, see JESSE DUKEMINIER \& JAMES E. KRIER, PROPERTY $935-36$ (3d ed. 1993).

17. The Uniform Marriage and Divorce Act encapsulates the modern position. Section 201 defines marriage as "a personal relationship . . . arising out of a civil contract." UNIF. MARRIAGE \& DIVORCE ACT $\$ 201,9$ A U.L.A. 160 (1973). On the range of contracting found in modern marriage behavior, see Marjorie M. Shultz, Contractual Ordering of Marriage: A New Model for State Policy, 70 CAL. L. Rev. 207 (1982). In the nineteenth century marriage was a status, not a package of default rules. There were "strong and stringent public expectations as to conduct and responsibility." Hendrik Hartog, Marital Exits and Marital Expectations in Nineteenth Century America, 80 GEO. L.J. 95, 97 (1991). "[B]eing married meant subjecting oneself to a known and coercive public relationship." Id. at 96.

18. The contractarian analysis of the foundational work of modern law and economics, R.H. Coase, The Problem of Social Cost, 3 J.L. \& ECON. 1 (1960), has reinforced these developments in recent decades.

19. For a succinct account of trusts for business and security purposes, see William F. Fratcher, Trust, in 6 INTERNATIONAL ENCYCLOPEDIA OF COMPARATIVE LAW \$\$ 44-51, at 37-42 (1973) [hereinafter Fratcher, INTERNATIONAL ENCYCLOPEDIA] (pamphlet print). A variety of current applications are discussed in COMMERCIAL ASPECTS OF TRUSTS AND FIDUCIARY OBLIGATIONS (Ewan McKendrick ed., 1992). 
example, investment in the American capital markets is now increasingly conducted through the medium of the investment trust (mutual fund) ${ }^{20}$ or the pension trust. ${ }^{21}$ In the nineteenth century, when the business corporation was in its infancy, great enterprises organized themselves as business trusts, ${ }^{22}$ begetting the regulatory response that is still known as antitrust. The flexibility of the trust has led to its use for securitization in corporate finance. A trust indenture underlies every bond issue, ${ }^{23}$ and deeds of trust are common vehicles for mortgage finance and for an array of other types of transaction. In these commercial usages, the contractarian character of the trust is transparent. ${ }^{24}$

Further, I exclude from this account the charitable trust, a special-purpose institution that inhabits the far end of the trust spectrum, where contractarian autonomy is more restrained. Charitable trusts are quasi-public institutions that must satisfy standards of public benefit articulated both in the common law ${ }^{25}$ and in the tax code and regulatory law. ${ }^{26}$

Also distinct from the present topic is the constructive trust, a species of equitable remedy ${ }^{27}$ comparable in function to the injunction or the decree of specific performance. The constructive trust is imposed coercively, as a means of correcting wrongdoing or remedying unjust enrichment, ${ }^{28}$ in settings that may initially be remote from trust. ${ }^{29}$ The ordinary private trust, by contrast, is a consensual relationship, voluntarily assumed by the trustee.

Thus, the present Article is devoted to the core function of the trust, as a regime for implementing gratuitous transfers through contractarian measures.

20. As of June 1995 , total net assets of mutual funds were $\$ 1.8$ trillion. INVESTMENT Co. INST., TRENDS IN MUTUAL FUND ACTIVITY tbl. 1 (June 1995).

21. Estimates for pension assets as of 1993 ranged between $\$ 4.6$ and $\$ 4.8$ trillion. JoHN H. LANGBEIN \& BRUCE A. WOLK, PENSION AND EMPLOYEE BENEFIT LAW 20 (2d ed. 1995).

22. See generally Herbert B. Chermside, Jr., Annotation, Modern Status of the Massachusetts or Business Trust, 88 A.L.R.3d 704 (1978).

23. See generally ROBERT I. LANDAU, CORPORATE TRUST 21-50 (4th ed. 1992) (outlining nature and use of trust indentures).

24. "[A]n indenture trustee is more like a stakeholder whose duties and obligations are exclusively defined by the terms of the indenture agreement." Meckel v. Continental Resources Co., 758 F.2d 811, 816 (2d Cir. 1985).

25. The doctrine of charitable purposes limits charitable trusts to the promotion of objects such as relief of the poor and the advancement of education, religion, and health. See RESTATEMENT (SECOND) OF TRusTs § 368 (1959).

26. The charitable trust was until the nineteenth century the only device available to private citizens for organizing eleemosynary endeavors. The charitable corporation is now the favored American form for more complex charitable entities. On the mechanics, see EDITH L. FISCH ET AL., CHARITIES AND CHARITABLE FOUNDATIONS $\$ 231$ (1974).

27. Discussed in I DAN B. DobBS, LAw of REMEdies $\$ 4.3(2)$, at 392-401 (2d ed. 1993).

28. "A constructive trust does not, like an express trust, arise because of a manifestation of an intention to create it, but it is imposed as a remedy to prevent unjust enrichment." RESTATEMENT OF RESTITUTION $\$ 160 \mathrm{cmt}$. a (1937). See generally GEORGE G. BOGERT \& GEORGE T. BOGERT, THE LAW OF TRUSTS AND TRUSTEES $\S 471$ (rev. 2d ed. 1978) [hereinafter BOGERT, TRusTs].

29. "The constructive trust is not in fact a trust, but a remedy which is explained by analogy to trusts." 1 DOBBS, supra note 27, at 401 . The fallacy of reasoning from the constructive trust to the real trust still appears on occasion. See, e.g., Deborah A. DeMott, Beyond Metaphor: An Analysis of Fiduciary Obligation, 1988 DUKE L.J. 879, 910. 


\section{From Conveyance to MANAGEMENT: THE Historical TRANSFORMATION OF THE TRUST}

Trusts are gifts. Most gifts are so simple that the donor has no reason to use a trust. The donor just delivers the asset, conveys realty, registers securities in the donee's name, or executes a deed of gift. ${ }^{30}$

The simple gift is a two-party transfer, from transferor (donor) to transferee (donee). The ordinary trust, by contrast, entails a three-party relationship, in which the donor (settlor) arranges with the trustee to divide the donee's interest between trustee and beneficiary. In the time-honored formulation, the trustee takes legal title to the property for the benefit of the beneficiary. "[T]he normal private trust is essentially a gift, projected on the plane of time and so subjected to a management regime."31

Inserting a trustee between the beneficiary and the donative interest is manifestly clumsy and costly. The donor who structures a gift in this way expects compensating advantages. The advantages and the uses of the trust have undergone fundamental change from the origins of the trust as a conveyancing device in the fourteenth and fifteenth centuries to its modern role as an institution for managing financial assets.

\section{A. The Early Trust as a Means of Conveyance}

The trust developed at the end of the Middle Ages, an epoch in which real estate was the principal form of wealth. The primary purpose of the trust was to facilitate the transfer of freehold land within the family. ${ }^{32}$ The law governing the transmission of freehold land was deeply afflicted by feudal restrictions meant originally to concentrate landholdings for military and related advantages. Long after the feudal system lapsed, burdensome feudal landholding rules endured. Particularly resented were (1) the rule requiring that freehold land pass by descent rather than by will, hence that land was not devisable; (2) the rigid shares of primogeniture and dower; and (3) the bizarre fiscal exactions, called wardship and marriage, that functioned as penal transfer

30. RESTATEMENT (SECOND) OF PROPERTY: DONATIVE TRANSFERS $\$ 31.1 \& \mathrm{cmt}$ b (1992) (delivery); id. $\$ 32.1$ (deed).

31. Bernard Rudden, Book Review, 44 MoD. L. REV. 610, 610 (1981).

Because trusts originate in gifts, black letter trust law has not required consideration to create a trust, "other than the transfer of the property" from settlor to trustee. RESTATEMENT (SECOND) OF TRUSTS $\$ 29$ (1959). The contract between settlor and trustee that is emphasized in this Article is supported by consideration. Trustees are now routinely compensated for their services. See infra text accompanying note 65. Even when not, the trustee's promise to hold the property for the beneficiary, which induces the settlor to transfer the property to the trustee, supplies bargained-for consideration within the meaning of RESTATEMENT (SECOND) OF CONTRACTS \$ 71 (1981).

32. Trusts for charitable purposes, in particular for the Franciscans, whose vow of poverty prevented them from owning property directly, also figured in the early history of the trust. 2 FREDERICK POLLOCK \& FREDERIC W. MAITLAND, THE HISTORY OF ENGLISH LAW BEFORE THE TIME OF EDWARD I, at 231, 237-38 (2d ed. 1898). 
taxes on minors. ${ }^{33}$ Landowners made conveyances in trust ${ }^{34}$ "in order to protect themselves and their families against the gross injustices of a system of land law which was centuries out of date. ${ }^{35}$ The trust allowed landowners "to make decent provision for their wives, daughters and younger sons and to prevent escheat" when the landholders were not survived by descendants. ${ }^{36}$

Transferring land to trustees neatly defeated the feudal restrictions. Suppose the prototypical case, in which the settlor conveyed freehold land to trustees, who agreed to hold the land for the settlor for life and then to convey to selected family members as the remainder beneficiaries. Because the trustees were the nominal owners of the freehold, when the settlor died none of the feudal rules that turned on descent were triggered. The trustees continued to own the land, and they would then convey it to the remainder beneficiaries as they had undertaken.

The trustees of these early trusts were mere stakeholders, little more than nominees, with no serious powers or responsibilities of management. Commonly, the beneficiaries lived on the land and managed it. In the example I have given, the trustees' only significant duty was to hold until the settlor's death, and then to put themselves out of business by conveying the freehold to the remainder beneficiaries. ${ }^{37}$

Long into the nineteenth century, the trust remained primarily a branch of the law of conveyancing. The trust was a means of transferring and holding title to real estate. Consult the early treatises on trusts, Gilbert ${ }^{38}$ (three editions from 1734 to 1811 ) and Sanders ${ }^{39}$ (five editions from 1791 to 1844), and you find works completely devoted to conveyancing. The modern law of fiduciary administration is simply not detectable in these books. Thus, well into the nineteenth century, the function of the law of trusts was remote from modern practice.

33. See generally 4 WILLIAM HOLDSWORTH, A HISTORY OF ENGLISH LAW 446-48 (3d ed. 1945) (16 vols. 1922-1966).

34. Technically, to uses, the precursor of the modern trust. The capsule account in the text collapses the saga of the late medieval use into the trust. For more detail, see, e.g., A.W.B. SiMPSON, A HISTORY OF THE LAND LAW 199-207 (2d ed. 1986).

35. Fratcher, INTERNATIONAL ENCYCLOPEDIA, supra note $19, \S 9$, at 12 .

36. Id. For detail on the techniques by which the trust (use) was manipulated in the fourteenth century to obtain will-like results, see J.M. BEAN, THE DECLINE OF ENGLISH FEUDALISM: 1215-1540, at 118-26, 148-56 (1968).

37. The trustees' duties were "to permit the [beneficiary] to occupy the land and enjoy the rents and profits," to defend the title at law, and "to convey the land as directed by the [beneficiary]." Fratcher, INTERNATIONAL ENCYCLOPEDIA, supra note 19, \$11, at 15 (citing Bacon and Coke).

38. I have not seen a first edition. Yale has the second edition: GEOFFREY GILBERT, THE LAW OF USES AND TRUSTS (London, Henry Lintot, 2d ed. 1741).

39. FRANCIS W. SANDERS, AN ESSAY ON THE NATURE AND LAWS OF USES AND TRUSTS, INCLUDING a Treatise on Conveyances at Common law; and Those Deriving Their EFFect from the STATUTE OF USES (London, E. \& R. Brooke, Ist ed. 1791). 


\section{B. Why Early Trust Law De-emphasized Contract}

Recall Maitland's insight that "a trust generally has its origin in something that we can not but call an agreement." ${ }^{.40}$ Maitland was asking why the early law did not immediately assimilate the trust to the law of contract. His answer has never been doubted. The common law of contract was too primitive to do the job. "If ... in the fourteenth century our law of contract had taken its modern form, I think that the courts of law would have been compelled to say 'Yes, here is an agreement; therefore it is a legally enforceable contract. ..."

\section{Failings of Covenant}

The case that the law of trusts must be able to remedy, quaintly known as the problem of the "faithless feoffees," arises when the trustees promise the settlor to devote the trust property to the beneficiaries and accept the property, but then appropriate it to themselves. ${ }^{42}$

By the late fourteenth century, covenant, the main contract writ of English law, suffered two grievous shortcomings that rendered it ineffectual as a means of enforcing the trust deal. Under the writ of covenant, the plaintiff needed to have the contract evidenced in a sealed instrument. ${ }^{43}$ If, therefore, no sealed instrument had been created, or if the deed had been destroyed, stolen, or lost, the case was beyond remedy in covenant.

Worse, the common law courts would grant only damages, not specific performance, to remedy breach of covenant. ${ }^{44}$ The trust beneficiary wanted the ancestral land, not money damages. ${ }^{45}$

40. MAITLAND, supra note 7 , at 28 .

41. Id. Maitland also thought that there was a strategic advantage to keeping trust enforcement in the ill-defined realm of the Chancellor's discretion in equity, rather than recognizing these deals at law. The feudal exactions that the trust avoided burdened most landowners but benefited overlords, especially the king, who were reluctant to lose the revenue. Id. at 29-30. By analogizing the early trust to the underlying estates in land, the Chancellors helped cover up (certainly from the king, perhaps from themselves) the extent of their departure from the feudal landholding regime. Equity follows the law, ran the maxim, and thus the departures were secreted in what was otherwise a law-imitating rubric. $I d$. at 32 .

42. For an example, recited in a petition to the Chancellor from the $1390 \mathrm{~s}$, see SELECT CASES IN CHANCERY: $1364-1471$, at 48-49 (William P. Baildon ed., London, Selden Soc'y vol. 10, 1896).

43. C.H.S. FIFOOT, HISTORY AND SOURCES OF THE COMMON LAW 257-58 (1949); A.W.B. SiMPSON, A History OF THE COMMON LAW OF CONTRACT 10 (1975).

44. FIFOOT, supra note 43 , at 259.

45. Debt, the other contract-type writ, was even less effective. Id. at 229-33. As late as Blackstone, contract was subordinated to conveyancing. See 2 WILLIAM BLACKSTONE, COMMENTARIES *440-70 (4 vols. 1765-69); see also 3 id. at *153-66. The first published treatise on contracts was J.J. POWELL, ESSAY UPON THE LAW OF CONTRACTS AND AGREEMENTS (Dublin, Chamberlaine \& Rice 1790). 


\section{Hostility to Assignment}

Deep into the nineteenth century, the common law greatly restricted the assignability of choses in action. ${ }^{46}$ By treating the beneficiary as having a property interest in the lands held in the trust, and not just a claim derived (assigned) from the settlor, the trust sidestepped the rule against assignment. ${ }^{47}$

\section{The Role of Procedure}

The shortcomings of the common law of contract were deeply connected to procedural weaknesses of the common law. ${ }^{48}$ The task of common law courts was to preside over the pleading of cases for jury trial. Common law judges did not investigate or find facts. There was no pretrial discovery system for gathering evidence, and thus, no way to examine alleged trustees about the trust deal or about their conduct. ${ }^{49}$ At first, the common law jury was selfinforming. By the sixteenth century, juries were hearing evidence presented at trial. However, the common law courts treated the parties to civil litigation as disqualified from testifying on account of their personal interest in the outcome, ${ }^{50}$ a rule that would have silenced most of the relevant persons in a trust case.

These weaknesses of common law civil procedure explain the insistence on the sealed instrument under the writ of covenant. The common law courts were simply incapable of taking evidence on the terms of a deal. By contrast, Chancery, the court that enforced the trust, proceeded by examining individual witnesses, including the parties, under oath. ${ }^{51}$ Informed through these disclosures, the Chancellor could declare the trust and grant specific

46. 7 HoldsworTH, supra note 33, at 532-44. See generally O.R. MARSHALL, THE ASSIGNMENT OF CHOSES IN ACTION (1950).

47. D.E.C. Yale, Introduction to 2 LORD NOTTINGHAM's CHANCERY CASES 89-90 (Selden SOc'y vol. $79,1961)$. This idea that the beneficiary's interest in the trust ("equitable title") was an interest in the trust property and not just a claim against the trustee became the basis for protecting the trust property from the personal liabilities of the trustee. Lord Chancellor Nottingham clarified the point in the 1670s, and successor Chancellors confirmed it in 1715 and 1725. Id. at 93.

48. See, e.g., Vernon V. Palmer, The Paths to Privity: The History of ThiRd Party BENEFICIARY CONTRACTS AT ENGLISH LAW 87-88 (1992).

49. Common law procedure "was virtually useless" for investigating "matters like secret instructions given by a feoffor to his feoffees to uses." Fratcher, INTERNATIONAL ENCYCLOPEDIA, supra note 19, $\$ 10$, at 13; see also 4 HOLDSWORTH, supra note 33, at 418-19.

50. On the origins of the rule, see 2 J.H. WIGMORE, EvidENCE $\$ 575$ ( $3 \mathrm{~d}$ ed. 1940); on the abolition of the rule, see Joel N. Bodansky, The Abolition of the Party-Witness Disqualification: An Historical Survey, 70 KY. L.J. 91 (1981-82).

51. W.T. Barbour, The History of Contract in Early English Equity, in 4 OXFORD STUDIES IN SOCIAL AND LEGAL HISTORY 1, 147-49 (Paul Vinogradoff ed., 1914). 
performance of its terms. ${ }^{52}$ Trust enforcement was, therefore, a creature of equitable procedure.

\section{Tracking the Common Law Estates}

Because the trust was primarily used as a passive device for holding ancestral land, it was easy enough to conceptualize the beneficiary's interest not merely as a personal claim against the trustee, but as a right in the underlying trust property ("equitable title") that the Chancellor would specifically enforce against the trustee's bare legal title.

\section{Testamentary Trusts}

After the barriers to devising real property were overcome in the $1660 \mathrm{~s},{ }^{53}$ it became quite common to create trusts by will, so-called testamentary trusts. The testator devised land or other property to persons named in the will, as trustees to hold for the beneficiaries designated in the will. The testamentary trust remains common in modern practice..$^{54}$

At first glance, contract formation seems a difficult enterprise for a decedent to conduct. We can understand why, in an age when the contractarian model itself was primitive, ${ }^{55}$ contemporaries did not characterize the testamentary trust as a contract between the decedent and the trustees named in the will. As a matter of mechanics, since the trust does not arise until the testator is dead, the trustees may be said to have no one with whom to contract.

Beneath the mechanics, however, lies the contractarian reality. As I explain in greater detail at the outset of Part IV of this Article, the defining elements of the law of contract are consensual formation and consensual terms. The prototypical transfer by trust agreement from living settlor to trustees exhibits both attributes. The trustee must voluntarily accept the trusteeship ${ }^{56}$ that is, agree to serve under the terms of the trust; and those terms are almost wholly within the parties' autonomy, since virtually all trust law is default law that can be altered in the trust instrument.

52. E.g., a petition from the $1390 \mathrm{~s}$, asking the Chancellor to examine allegedly wrongdoing trustees, in order to restore the petitioner to "her right in the said lands and tenements, as by the examination before you, most gracious Lord, shall be found and proved." SELECT CASES IN CHANCERY: 1364-1471, supra note 42 , at $48-49$.

53. As part of the Restoration settlement, the Statute of Tenures of 1660 abolished the military tenures. 12 Car. 2, ch. 10 (1660). The crown was compensated with alternative revenues-from excise taxes on beer, cider, and spirits. A.D. HARGREAVES, AN INTRODUCTION TO THE PRINCIPLES OF LAND LAW 35 (3d ed. 1952).

54. Endorsed under RESTATEMENT (SECOND) OF TRUSTS $\$ 17(c)$ (1959).

55. See discussion supra text accompanying note 41 .

56. "[T] he trustee is not under a duty to administer the trust unless he accepts." RESTATEMENT (SECOND) OF TRUSTS $\$ 169 \mathrm{cmt}$. a (1959). 
Both these defining traits persist when a trust is created by will. The settlor has essentially the same freedom to tailor the terms of the trust under a will as with an inter vivos trust. Similarly, the persons designated as trustees have the same right to decline to serve as trustees if the terms are not to their liking. Accepting a testamentary trusteeship is a consensual act. The appointment comes from the probate court, standing in, as it were, for the decedent. The testamentary trustee decides whether to accept the trust on the terms contained in the instrument and in the background default law of trusts. The person designated either declines the appointment or agrees to the trust deal. To be sure, the deal is of the take-it-or-leave-it type, like the movietheater ticket or the vending-machine contract; there is no negotiating terms with a decedent.

Notice in this connection that executorship is a consensual fiduciary relationship, like trusteeship. You cannot be appointed executor of a will against your wishes. ${ }^{57}$ Furthermore, the substantive law of estate administration is mostly default law that the testator's will can alter, apart from measures designed to protect creditors' rights and other external interests. Thus, executorship, like trusteeship, exhibits the twin features of contractarianism-consensual formation and consensual terms. The fiduciary law applicable to executors is virtually identical to that governing trustees.

\section{The Appearance of the Management Trust}

The feudal restrictions on the transfer of real property that gave rise to the conveyancing-type trust disappeared piecemeal from the late seventeenth to the early twentieth centuries. Although feudal land law no longer needs evading ${ }^{58}$ the trust has endured because it has changed function. The trust has ceased to be a conveyancing device for holding freehold land and has become instead a management device for holding financial assets.

The management trust is a response to the radical change away from family real estate as the dominant form of wealth. As Roscoe Pound observed in an arresting epigram, "Wealth, in a commercial age, is made up largely of promises." 59

57. See UNIF. Probate CODE $\S$ 3-301(a)(3), 8 U.L.A. 246 (1990) (application procedures); id. \$ 3-308, 8 U.L.A. 253 (appointment).

58. Indeed, since 1925, statute in England has mandated the trust form for life estates and for concurrent estates in land. See M.P. THOMPSON, MEGARRY's MANUAL OF THE LAW OF REAL PROPERTY 223 (7th ed. 1993); Ronald Maudsley, Escaping the Tyranny of Common Law Estates, 42 Mo. L. REv. 355, $362-63$ (1977).

59. RosCoe Pound, AN INTROduction to the PhILOSOPHy of LAW 236 (1922). 


\section{Financial Assets}

Modern wealth takes the form of financial assets-for example, stocks, bonds, mutual fund shares, insurance and annuity contracts, pension plans, and bank deposits. ${ }^{60}$ The modern trust typically holds a portfolio of these complex financial assets, which are contract rights against the issuers. This portfolio requires active and specialized management, in contrast to the conveyancing trust that merely held ancestral land.

Modern forms of wealth allow the settlor to devolve more options on the trustee in the dispositive provisions of trusts, that is, in allocating and distributing beneficial interests. By comparison with the interests possible in a trust of ancestral land, the modern trust fund invites greater flexibility to accumulate, distribute, or spend trust funds on behalf of beneficiaries.

\section{Institutional Trusteeship}

Connected to the change in the nature of trust assets from realty to financial assets, and in the function of trusteeship from stakeholding to management, has come a change in the identity of trustees. Trustees of old were unpaid amateurs, that is, family and community statesmen who lent their names and their honor to a conveyancing dodge. Still in Maitland's day, "[a]lmost every well-to-do-man was a trustee ...."

Private trustees still abound, but the prototypical modern trustee is the feepaid professional, whose business is to enter into and carry out trust agreements. These entities thrive on their expertise in investment management, trust accounting, taxation, regulation, and fiduciary administration. In the United States ${ }^{62}$ these institutional trustees are commonly corporate fiduciaries, ${ }^{63}$ that is, profit-seeking enterprises, often listed on the New York

60. The other distinctively modern form of wealth, human capital (that is, skill) does not lend itself to being a trust or portfolio asset, although trusts to support the education of beneficiaries are common enough. For discussion of how the growing importance of human capital has altered the patterns of intergenerational wealth transfer, see John H. Langbein, The Twentieth-Century Revolution in Family Wealth Transmission, 86 MiCH. L. REV. 722 (1988).

61. FREDERIC W. MAITLAND, Trust and Corporation, in SElected EsSAYs 141, 175 (H.D. Hazeltine et al. eds., 1936). When the German civil code came into effect at the turn of the twentieth century, wrote Maitland, the English lawyer "would remember how he was a trustee and how almost every man that he knew was a trustee," and he would wonder why the German code contained no provision for trusts. Id. at 143.

62. In England and the Commonwealth, statutes have facilitated the growth of a Public Trustee system to supplement private institutions, especially for serving small accounts. The Public Trustee system appears to have originated in New Zealand. See C.W. VENNELl, A CENTURY OF TRUST: A History OF THE NEW ZEAland PUblic TRust OfFICE: 1873-1973 (1973). Public Trustee legislation was enacted in England in 1906. See Public Trustee Act, 6 Edw. 7, ch. 55 (1906). Canadian jurisdictions have followed. See D.W.M. WATERS, LAW OF TRUSTS IN CANADA $97-99$ (2d ed. 1984). See generally BOGERT, TRusTS, supra note $28, \S 133$.

63. The industry's origins are described in JAmES G. SMTth, THE DEvelopment of Trust COMPANIES IN THE UNITED STATES (1928). 
Stock Exchange and called something like the Wells Fargo Bank or the Northern Trust Company.

The corporate fiduciary brings to the business of trust administration not only special skills but also deep pockets. Under the liability regime of trust law, the trustee places its substantial capita ${ }^{64}$ at risk in the event that the trustee misperforms its duties. This exposure of the trustee's capital informs the modern trust deal, effectively insuring the beneficiary against many potential harms and forming part of what the settlor buys when selecting a corporate fiduciary. The liability risk creates a further incentive for the trustee to perform the trust deal faithfully.

Originally, the law of trusts made no provision for compensating trustees because the gentleman trustee serving as a family stakeholder required no pay. Legislation was needed to overcome the presumption against trustee compensation. ${ }^{65}$ For Wells Fargo or Northern Trust, the administration of trusts is a business, supported by ever more aggressive marketing. Institutional trustees serve pursuant to a compensation deal, sometimes negotiated for the particular trust, sometimes based on the bank's published fee schedule, and sometimes dependent on legislated default law. The hustle of the marketplace ${ }^{66}$ that produces such trusteeships is hard to reconcile with the doctrinal insistence on denying the contractual character of the settlor-trustee relationship. Manifestly, these things are deals.

Another virtue of the corporate fiduciary is longevity. Corporate fiduciaries are institutions of perpetual succession. ${ }^{67}$ If I appoint my brother-in-law as the trustee, I need to arrange for the consequences of his mortality. I need to designate successor trustees, or design a mechanism for identifying potential successors, and hope that the persons proposed will agree to serve. By contrast, when I have cut my trust deal with Northern Trust and the account officer on the trust dies or leaves, Northern Trust simply shifts the account to another desk. Northern Trust will outlive my trust, even if the trust runs for a generation or two.

One measure of the ubiquity of professional trusteeship is the rule, now widely codified, that the standard of care applicable to a professional trustee

64. The state banking codes that authorize corporations to serve as fiduciaries commonly impose reserve and capital requirements. See, e.g., CAL. FIN. CODE $\$ \$ 1500-1591$ (West 1989 \& Supp. 1995).

65. The American state legislation is collected in BOGERT, TRUSTS, supra note $28, \S 975$.

66. In the trade literature, the marketing of bank trust services is not easily distinguished from vacuum cleaner sales. The senior vice president for marketing at Boatmen's Trust Company, St. Louis, urges "a strong incentive compensation program" to reward "the selling efforts of the sales staff." William F. Ottinger, Making the Case for Trust, BANK MGMT., Nov. 1991, at 37, 38. “At Boatmen's, the compensation program is based on the first year's [trustee] fees. The banker who refers the account receives $20 \%$ of the first year's fees and his department receives $40 \%$. This is in addition to bonuses paid to the trust sales staff and/or the trust administrators and trust investment managers." Id. at 41.

67. Drafters commonly provide that when a corporate fiduciary merges with another, the survivor shall be the trustee. 
is the standard of the reasonable professional. ${ }^{68}$ Another indication that professional conduct in important trust functions has become the benchmark of American trust law is the growing pressure on amateur trustees to yield to professionals. The Restatement (Third) of Trusts: Prudent Investor Rule reverses the old rule that forbade trustees to delegate important trust functions. It imposes a duty on trustees to assess their own competence, in order to decide "whether, to whom and in what manner to delegate fiduciary authority in the administration of a trust." ${ }^{69}$ The Uniform Prudent Investor Act of 1994 strongly accords. ${ }^{70}$

A century after Maitland reported that "[a]lmost every well-to-do man was a trustee,"71 institutional trusteeship is ever more the norm.

\section{Safeguard: From Disempowerment to Fiduciary Obligation}

The trust relationship of necessity puts the beneficiaries of a trust at the peril of the trustees' misbehavior-for example, if the trustees should misappropriate or mismanage the trust's assets. The central concern of modern trust law is to safeguard against those dangers.

The changed character of trust assets has brought about a significant change in the way trust law protects beneficiaries. An older scheme devoted to restricting trustees' powers has yielded to the surprisingly modern set of rules that trust lawyers call the law of fiduciary administration. Although the substitution of fiduciary law for law restricting the powers of the trustee is a central event in the development of modern trust law, the scholarly literature has not, so far as I am aware, noticed it.

In the first centuries of the trust, when trustees were mostly stakeholders for ancestral land, they were kept tightly in check by being disabled from doing much with the trust property. ${ }^{72}$ The default law supplied no trustees' powers. The trustees had only those powers that the trust instrument expressly granted, which were typically few, since the trustees' job was simply to hold and then to convey to the remainderpersons. Stakeholder trustees did not need to transact. Joseph Story summarized the law for Americans in his treatise on

68. "A trustee who has special skills or expertise, or is named trustee in reliance upon the trustee's representation that the trustee has special skills or expertise, has a duty to use those special skills or expertise." UNIF. PRUDENT INVESTOR ACT $\$ 2(f), 7 B$ U.L.A. 20 (1994) (derived from UNIF. PROBATE CODE $\S 7-302,8$ U.L.A. 555 (1990)); accord RESTATEMENT (SECOND) OF TRUSTS $\$ 174$ (1959).

69. RESTATEMENT (THIRD) OF TRUSTS: PRUDENT INVESTOR RuLE $\$ 171$ (1992) (partial revision of the Second Restatement, promulgated in 1992, and limited to investment and related issues).

70. See UNIF. PRUDENT INVESTOR ACT \$ 9, 7B U.L.A. 26 (1994). I have elsewhere explained the background of these developments. See John H. Langbein, Reversing the Nondelegation Rule of TrustInvestment Law, 59 Mo. L. REV. 105 (1994).

71. MAITLAND, supra note 61 , at 175 .

72. Each trustee was typically one of several co-trustees, and by requiring the trustees to act with unanimity, the default rule gave each trustee a veto power for superintending the others. The unanimity rule survives in RESTATEMENT (SECOND) OF TRUSTS $\$ 194$ (1959). 
Equity Jurisprudence in 1836: "[T]he trustee has no right (unless express power is given) to change the nature of the estate, as by converting land into money, or money into land ....".73

Indeed, the modern trustee still needs to look to the trust instrument or to remedial trustees' powers legislation for empowerment. "In the absence of legislation, a trustee has no power whatever by virtue of his office; his only powers are those expressly or impliedly conferred upon him by the terms of the trust." $" 74$

The need for active administration of the modern trust portfolio of financial assets rendered obsolete this scheme of disempowering the trustee to transact with the trust property. The modern trustee conducts a program of investing and managing the assets that requires extensive discretion to respond to changing market forces.

A strategy of maximum empowerment displaced the former law, initially in professionally drafted trust instruments, and then in modern systems of default law such as the Uniform Trustees' Powers Act. These statutes empower trustees to engage in every conceivable transaction that might wrest market advantage or enhance the value of trust assets. ${ }^{75}$

Connected to the movement to empower trustees for active management of modern trust assets has been the volte face in the rules governing the responsibilities of persons transacting with trustees and the earmarking of trust property. Before legislation revolutionized the field, trust law purported to protect the bona fide purchaser of trust assets, but as a practical matter made it "very difficult to qualify as a bona fide purchaser."

The traditional rule, still codified in the Restatement (Second) of Trusts, turns on notice: The purchaser who "has notice that the trustee is committing a breach of trust in making the transfer"77 is unprotected against the beneficiaries' claim to recover the trust asset or its proceeds. In tandem with the earmarking rule, which required a trustee to take title to trust assets "as

73. 2 JOSEPH STORY, COMMENTARIES ON EQUITY JURISPRUDENCE, AS ADMINISTERED IN ENGLAND AND AMERICA $\$ 978$ (Boston, Little \& Brown 1836). Story was following Ballow's prominent treatise, published as 2 JOHN FonblanQue, A TREATISE of EQuiTY 170 n.a (London, A. Strahan \& W. Woodfall, ist ed. 1793).

74. Fratcher, INTERNATIONAL ENCYCLOPEDIA, supra note 19, $\$ 81$, at 66 (citing RESTATEMENT (SECOND) OF TRUSTS $\$ 186(1959)$ ).

75. Included are the powers to retain assets; receive additions; operate a business; invest and reinvest; buy, sell, or lease an asset; exchange, partition, improve, or abandon an asset; exploit minerals; grant options; vote securities; borrow money; insure; litigate; amortize; and employ agents. UNIF. TRUSTEES' POWERS ACT \$3, 7B U.L.A. 746 (1964).

Corporation law experienced a comparable movement from the restricted corporate powers that produced the old case law about ultra vires acts, to the modern statutes that grant "corporations legal powers almost coextensive with those of natural persons ... to engage in any lawful line or lines of business." RoberT C. ClaRK, CoRporate LAW $\$ 16.1$, at 676 (1986) (footnotes omitted). As in trusts, so in corporations, expanded fiduciary law was the alternate safeguard that replaced restrictions on powers.

76. Fratcher, INTERNATIONAL ENCYCLOPEDIA, supra note $19, \S 98$, at 80 .

77. RESTATEMENT (SECOND) OF TRUSTS $\$ 296$ (1959). 
trustee," $" 78$ anyone purchasing land or securities so titled was effectively placed on notice to inquire into the trustee's power of sale. Since, however, trustees had no intrinsic power of sale, these rules required the prospective purchaser to examine the trust instrument to determine whether it granted the trustee the power to sell the asset in the pending circumstances. These rules "effectively deter[red] third parties from dealing with trustees." "9

Statute has now set these disabling rules out of force. Nominee legislation in every American state has overcome the main earmarking requirement, which made "it difficult to use corporate stock as a trust investment." now authorized to register trust holdings of corporate stock in a fashion that conceals the trust interest. ${ }^{81}$ Furthermore, the Uniform Fiduciaries Act, the Uniform Commercial Code, and the Uniform Trustees' Powers Act provide that the purchaser is no longer under a duty to inquire into the trustees' transactional authority merely because the purchaser has notice that the seller is a fiduciary. ${ }^{82}$ For example, section 7 of the Uniform Trustees' Powers Act provides that an outsider purchasing or otherwise transacting with trust property "may [assume] without inquiry" both "the existence of trust power and their proper exercise by the trustee." ${ }^{133}$ The modern trustee has been empowered to transact with trust assets on an equal footing with other market actors.

Empowering the trustee to transact freely in the financial markets has shifted the locus of protection for beneficiaries from powers law to fiduciary law. Whereas disempowerment prevented the trustee from acting, modern trustees' powers law confers vast managerial discretion. Discretion entails the risk of harm as well as the opportunity to enhance the trust assets. To safeguard beneficiaries against abuse of this discretion, trust fiduciary law has developed as the functional replacement for the former scheme of trustee disability. Fiduciary law imposes two broad standards, loyalty and care, that regulate the exercise of the discretion that modern trustees' powers law bestows.

I discuss the contractarian character of trust fiduciary law below, in Part IV. The present point is simply that trust fiduciary law bears a modern vintage. Glance at the classic treatises. Neither Gilbert ${ }^{84}$ nor Sanders ${ }^{85}$ nor

78. Id. $\$ 179 \mathrm{cmt} . \mathrm{d}$.

79. Peter T. Wendel, Examining the Mystery Behind the Unusually and Inexplicably Broad Provisions of Section Seven of the Uniform Trustees' Powers Act: A Call for Clarification, 56 Mo. L. REV. 25,31 (1991).

80. Fratcher, INTERNATIONAL ENCYCLOPEDIA, supra note $19, \S 79$, at 62 .

81. See BOGERT, TRUSTS, supra note 28, $\$$ 596; 2 A SCOTT \& FRATCHER, TRUSTS, supra note 3 , $\$ 179.5$, at 519-25; Fratcher, INTERNATIONAL ENCYCLOPEDIA, supra note 19, $\$ 79$, at 63-64.

82. Wendel, supra note 79 , at 32-34, provides detail on the several uniform acts.

83. UNIF. TRuSTEES' POWERS ACT $\$ 7$, 7B U.L.A. 758 (1964).

84. GILBERT, supra note 38 .

85. SANDERS, supra note 39. 
Fonblanque (Ballow) ${ }^{86}$ nor Story ${ }^{87}$ covers trust fiduciary law. Not until Lewin $^{88}$ (sixteen editions, from 1837 to 1964) in England and Pomeroy ${ }^{89}$ (five editions, from 1882 to 1941) in America do we find treatises covering what we now recognize as fiduciary issues, although still in a cramped fashion, somewhat as an afterthought. The success of the midcentury treatises-Bogert and Scott-in running Pomeroy off the American market results from their extensive coverage of the new trust law, that is, of trust fiduciary law.

To be sure, principles of trust fiduciary law can be traced well back to the eighteenth century. Keech v. Sandford,$^{90}$ the foundational case on what we now generalize as the duty of loyalty, was decided in 1726 . The themes of early trust investment law (the preoccupation with safety of corpus and the preference for government bonds and well-secured first mortgages) were also articulated in England in the eighteenth and nineteenth centuries, ${ }^{91}$ then remolded into the prudent investor standard across the nineteenth and twentieth centuries in the United States. ${ }^{92}$ But these doctrinal impulses were not matters of great consequence for contemporary practice. Only within the past century or so, as financial assets displaced ancestral land from the typical trust, have trustees come routinely to exercise the levels of discretion over trust property that bring the fiduciary standards of loyalty and care into frequent play. As a practical matter, trust fiduciary law has been twentieth-century law.

\section{PRobing the ObJections to Contractarian ANALYsis of the MODERN TRUST}

I return to the question of why the doctrinal tradition of the modern law of trusts has resisted the contractarian account. The history helps us understand why the theme of trust as contract was suppressed in the formative era ${ }^{93}$ of the trust. But the contractarian account should have become more prominent in light of the great changes that have occurred in the character and function of the modern trust. The management trust holds a portfolio of financial assets

86. FONBLANQUE, supra note 73.

87. STORY, supra note 73.

88. I have used Yale's earliest copy: ThOMAs Lewin, A PRACTICAL TREATISE ON THE LAw OF TruSTS AND TRUSTEES $* 288-* 323$ (Philadelphia, John S. Littell 1839).

89. E.g., 2 JoHN N. POMEROY, A TREATISE ON EQUITY JURISPRUDENCE AS ADMINISTERED IN THE UNITED STATES OF AMERICA $\$ \S 1071-74$ (San Francisco, A.L Bancroft \& Co., Ist ed. 1882) (investment); id. $\$ \$ 1075-78$ (loyalty).

90. 2 Eq. Cas. Ab. 741, Cas. Ch. 61, 25 Eng. Rep. 223 (1726). On the origins, see Walter G. Hart, The Development of the Rule in Keech v. Sandford, 21 LAW Q. REv. 258 (1905).

91. A useful account of the history of the English law appears in A.H. OOSTERHOFF, TRUSTEES' POWERS OF INVESTMENT: A STUdY PREPAREd AT THE DiRECTION OF THE ONTARIO LAW REVIEW COMMISSION 6-23, 35-44, 49-59 (1970).

92. On the history of trust investment law in the United States, see the important article, Lawrence M. Friedman, The Dynastic Trust, 73 YALE L.J. 547, 551-72 (1964). See generally BOGERT, TRUSTS, supra note 28 , \$\$ 613-14.

93. I borrow the phrase. See Roscoe Pound, THE Formative ERA OF AMERICAN LAW (1938). 
that require incessant administration, often including further contracting with the portfolio assets. The management trust has brought forth a new type of trustee-the corporate fiduciary, a service provider for hire, hardly different in function from the professionals who contract to supply services in industry, commerce, finance, law, accounting, and so forth. Our default law has undergone a revolution meant to facilitate the management trust. Expansive trustee powers have liberated the trustee for transacting, while a new fiduciary law (deeply contractarian, as I discuss in Part IV) has been devised to protect trust beneficiaries.

Thus the puzzle: Contract suffuses the modern trust relationship in these many ways, yet our doctrinal account of the trust remains inimical to recognizing the contractarian basis of the trust. Recall the language of the first and second Restatements: "The creation of a trust is conceived of as a conveyance of the beneficial interest in the trust property rather than as a contract." 94

The resemblance of trust and contract is a topic that was discussed at the end of the nineteenth century and into the twentieth century. This literature is not much remembered, in part because the question was framed in an archaic way, purportedly addressing "the nature of the cestui's interest in the trust." Cestui (short for cestui que trust) is the old term for the beneficiary of a trust. The central question was whether the beneficiary's interest was proprietary or "merely" promissory - "whether the beneficiary's interest is an in rem interest in the trust res itself, or whether the beneficiary has merely an equitable claim in personam against the trustee.",96

The central figures in this dialogue were Frederic W. Maitland, the greatest scholar of the common law, who got the contractarian basis of the trust right; and Austin W. Scott, who got it wrong, but had the fortitude to write his error into the Restatement of Trusts.

Maitland's lectures on Equity dwell on the theme that the trust is a "bargain"97 that the Chancellor would enforce, "an obligation, in point of fact a contract though not usually so called." Even though the trust arises upon the transfer of property to the trustee, the trust

originates in an agreement. ... [E]ven if there is no benefit to the promisor, the trustee, there is at all events detriment to the promisee, the [settlor], since he parts with legal rights, with property and with possession. Men ought to fulfil [sic] their promises, their agreements;

94. RESTATEMENT (SECOND) OF TRUSTS $\$ 197 \mathrm{cmt}$. b (1959), previously noticed, supra text accompanying note 12 .

95. See sources cited infra notes 102 and $\mathbf{1 1 6 .}$

96. Sarajane Love, Imperfect Gifts as Declarations of Trust: An Unapologetic Anomoly, $67 \mathrm{KY}$. L.J. 309, 313 n.11 (1979).

97. MAITLAND, supra note 7 , at 29.

98. Id. at 110 . 
and they ought to be compelled to do so. ... [T] to enforce a personal right, a jus in personam, not a real right, a jus in rem-he begins to enforce a right which in truth is a contractual right, a right created by a promise. 99

Indeed, Maitland thought that no functional justification, but only the imprint of the historical experience with the conveyancing trust, ${ }^{100}$ could explain our insensitivity to the contractarian basis of the modern trust. He found it "utterly impossible for us to frame any definition of a contract which shall not include the acts by which ninety-nine out of every hundred trusts are created, unless we have recourse to the expedient of adding to our definition of contract a note to the effect that the creation of a trust is to be excluded."101

Why does present-day doctrine embrace an anticontractarian account dependent upon historical circumstances that no longer pertain? The most influential effort to resist Maitland's contractarian analysis of the trust was an article that Scott published in the Columbia Law Review in 1917. Even while recognizing "that in the creation of a use or trust there are often found all the elements which are found in the creation of a contract,"102 Scott insisted on viewing " $[t]$ he creation of a use or trust ... as a legal transaction quite different from the creation of a contract."103

Scott advanced three main arguments in the Columbia paper. He observed that contract cannot account for the two-party trust-that is, the declaration of trust, in which the settlor also serves as the trustee. ${ }^{104}$ As was said at the outset of this Article, when the settlor is the sole trustee, there can be no deal between settlor and trustee. ${ }^{105}$ But that is no answer to the contention that the conventional three-party trust, centered in the deal between settlor and trustee, exhibits the contractarian character that Maitland emphasized. (I devote some further attention to the declaration of trust in the appendix to this Article. I point out that the declaration sometimes serves as a way station to the creation of a true third-party trust, and that in other settings the declaration is a label that is used to validate transfers that are not in function trusts.)

99. Id. at 29.

100. Id. at 110-11.

101. Id. at 111. Compare Bernard Rudden's observation: "The orthodox explanation, given in terms of the traditional distinction between law and equity, provides only an historical and not a rational account of the trust." Bemard Rudden, Things as Things and Things as Wealth, 14 OXFORD J. LEGAL STUD. 81, 89 (1994). Likewise, the concept of legal title in the trustee is a mere historical convention, a way of speaking. Id. at 88 .

102. Austin W. Scoth, The Nature of the Rights of the Cestui Que Trust, 17 COLUM. L. REv. 269, 270 (1917) [hereinafter Scott, Rights]; see also Austin W. Scott, The Fiduciary Principle, 37 CAL. L. REv. 539, 540 (1949) (acknowledging "undertaking" as the basis of fiduciary obligation: "Who is a fiduciary? A fiduciary is a person who undertakes to act in the interest of another person. It is immaterial whether the undertaking is in the form of a contract. It is immaterial that the undertaking is gratuitous.")

103. Scott, Rights, supra note 102, at 269.

104. Id. at 270 .

105. See supra text accompanying note 5 . 
Scott further argued that the English law of contract did not recognize the third-party-beneficiary contract, the type of contract necessary to enforce trusttype deals. Scott concluded the Columbia paper with the contention that a contractarian account of the trust could not explain equitable tracing against nonparties to the trust deal. By the 1930s, when Scott drafted the Restatement of Trusts, he was pointing to a further ground: fear that a contractarian account could undermine the integrity of the trust in the dawning procedural system that was emerging from the fusion of law and equity. These claims turn out to be insubstantial.

\section{A. Third-Party-Beneficiary Contracts}

The analogy between the conventional three-party trust and the contract presupposes a system of contract law that recognizes third-party-beneficiary contracts. Scott began his Columbia article by claiming that "there is a dispute as to the right of the beneficiary of a contract to enforce the contract."106 This position was archaic when Scott advanced it. The movement to enforce third-party-beneficiary contracts was by then deeply entrenched in American law, ${ }^{107}$ although English law still refuses to recognize them. ${ }^{108}$

The relation between trust and contract was a central topic in Lawrence $v$. Fox, ${ }^{109}$ the landmark New York case of 1859 that legitimated the third-partybeneficiary contract in American law. Justice Gray's opinion reasoned that trust exemplifies contract, hence that third-party-beneficiary contracts have long been enforced in trust and might as well also be admitted in contract law. "The duty of the trustee to pay the [beneficiaries], according to the terms of the trust, implies his promise to the latter to do so."110 The principle of enforcing third-party claims "has been applied to trust cases, not because it was exclusively applicable to those cases, but because it was a principle of law, and as such applicable to those cases." 111 Thus, enforcing trusts is but an instance of the larger principle that third-party beneficiaries are entitled to enforce promises made for their benefit. Indeed, the point has long been made that trust is the way that the English enforce their third-party-beneficiary

106. Scott, Rights, supra note 102, at 270 .

107. The development of American third-party-beneficiary law is brilliantly recounted in Anthony J. Waters, The Property in the Promise: A Study of the Third Party Beneficiary Rule, 98 HARV. L. REV. 1109 (1985). Enforcement of third-party-beneficiary contracts in the United States today is firmly settled. See RESTATEMENT (SECOND) OF CONTRACTS $\$ 302(1)$ (1981).

108. In his treatise, first published in 1939, Scott was quite critical of the English refusal to enforce third-party-beneficiary contracts. I SCOTT \& FRATCHER, TRUSTS, supra note 3, \$ 14.4, at 196-200.

109. 20 N.Y. 268 (1859).

110. Id. at 274 .

111. Id. 
contracts. ${ }^{112}$ The precocious development of trust removed the pressure from English law to recognize the third-party-beneficiary contract.

Accordingly, Scott was right to direct attention to the functional equivalency of trusts and third-party-beneficiary contracts, but wrong to find in that relationship any obstacle to the contractarian analysis of the modern trust. The better view is Lawson's, already quoted, that "the three-cornered relation of settlor, trustee, and [beneficiary] ... is easily explained in the modern law in terms of a contract for the benefit of a third party."113

\section{B. Implications of Equitable Tracing}

Scott pointed to equitable tracing as the test case for his view that the beneficiary of a trust is "the equitable owner of the property held by the trustee" and has "proprietary rights in the trust property."114 In the case in which the trustee transferred trust property to an outsider who did not supply value, the Chancellor would enforce the beneficiary's claim to compel the transferee to return the asset to the trust even though that transferee was not a party to the trust deal between settlor and trustee. Scott followed James Barr Ames in treating equitable tracing against transferees as implementing a policy to prevent unjust enrichment, but Scott argued that "this reason necessarily involve[d] a recognition that the [beneficiary] has an interest in the property." 115

Two issues later in the Columbia Law Review, Harlan Fiske Stone published a swift reply. He objected that "the real reason for the liability of third persons is the unconscientious interference with the right in personam which the [beneficiary] has against the trustee," 116 and not any right in rem in the trust asset. Stone was showing that the Chancellor's willingness to enforce the beneficiary's interest against the transferee protects the beneficiary's (and the settlor's) reliance upon the trustee's promise, and thus does not need to be conceptualized as vindicating a property right in the trust asset. The decree runs against the purchaser on account of his conduct, because he suffers no detriment when he gives no value. The Chancellor's decree embodies a judgment about how far to impinge on outsiders to the trust deal

112. See, e.g., Arthur L. Corbin, Contracts for the Benefit of Third Persons, 46 LAW Q. REv. 12, 16-17 (1930).

113. LAWSON, supra note 10, at 200. Scott inserted in the Restatement the innocuous black letter proposition that "[a] contract for the benefit of a third party is not a trust." RESTATEMENT (SECOND) OF TRUSTS $\S 14$ (1959). The Restatement is certainly correct to say that not every third-party-beneficiary contract intends to create a trust relationship, and indeed, most do not. But as Lawson suggests in the passage quoted in the text, the Restatement provision would be false if subject and predicate were reversed to say, "a trust is not a contract for the benefit of a third party." It is.

114. Scott, Rights, supra note 102, at 275.

115. Id. at 283. (1917).

116. Harlan F. Stone, The Nature of the Rights of the Cestui Que Trust, 17 ColuM. L. REV. 467, 477 
between settlor and trustee in order to vindicate that deal. The policies that are being balanced do not turn on understanding the beneficiary's interest as property rather than contract.

Stone's colleague, Richard Powell, took Stone's view into his treatise, Powell on Real Property. ${ }^{117}$ Powell wrote: "That the beneficiary's interest has gained protections against a large proportion of possible challengers does not require treating it as an 'in rem' right enforceable against all the world." 118 Powell found American statutory authority on both sides of the question. For states having no statutory provision, he recommended "[t]he traditional and historically sound view," which "is that the beneficiary still has only a chose in action with supplementing protections against third persons." 119

Stone and Powell anticipated the modern jurisprudential consensus against deducing outcomes by categorizing something as property (or contract). Ernest Weinrib states it well: "[P]roperty is itself merely the label for that crystallized bundle of economic interests which the law deems worthy of protection."120 Accordingly, "affixing the label of property constitutes a conclusion not a reason. The difficulty is not to supply a label but to identify the protected interest." 121 Part IV of this Article shows why the better set of reasons for enforcing the trust arise from a contractarian analysis.

Once again, it is impossible to side with Scott in thinking that the remedial system of equity brands the law of trust as anticontractarian. Rather, equitable tracing is simply a mode of enforcing the trust deal.

\section{C, The Effect of Fusion on Trust Enforcement}

By the 1930s, when Scott was embedding anticontractarianism into the Restatement of Trusts, the themes of his Columbia article had receded before a new concern. Scott was alarmed over the movement then underway to bring about the fusion of law and equity in American civil procedure and judicial administration. He worried that fusion might remove the law of trusts from the nurturing hand of the specialist equity bench, and indeed, that fusion might cause trust litigation to be subjected to jury trial. In England and in most leading American jurisdictions, the law of trusts had been the province of separate equity courts or equity divisions. Scott used the Restatement to

117. 4 Richard POWEll, POWEll ON ReAl PROPERTY I 513[3], at 41-142 (Patrick J. Rohan ed., 1995). Powell summarizes "two competing views." One "is that a beneficiary has only a chose in action along with supplementary protections against interferences by third persons," the other "that the trust beneficiary owns an equitable right 'in rem' in the trust property." Id.

118. Id. at $41-145$.

119. Id. at 41-149.

120. Ernest J. Weinrib, The Fiduciary Obligation, 25 U. TORONTO L.J. 1, 10 (1975); cf. Thomas C. Grey, The Disintegration of Property, 22 Nomos 69 (1980).

121. Weinrib, supra note 120 , at 11 (footnote omitted). 
reinforce the authority of the specialist equity bench against the imponderables of fusion.

Recall that the Restatement says: "The creation of a trust is conceived of as a conveyance of the beneficial interest in the trust property rather than as a contract." 122 Why emphasize conveyancing and disavow contract? The official comment explains its concern to restrict trust matters to the specialist equity courts. "[Q]uestions of the administration of trusts have always been regarded as of a kind which can adequately be dealt with in a suit at equity rather than in an action at law, where questions of fact would be determined by a jury and not by the court." ${ }^{23}$ The trustee's "mere" words of promise do "not give the common-law courts concurrent jurisdiction over the administration of the trust," 24 and the trustee's "agreeing to perform his duties as trustee does not make a contract to perform the trust enforceable in an action at law." 125

Thus, for Scott, having the Restatement deny the contractarian character of the trust was a means of buttressing the jury-free preserve of equity judges over trust administration at the historical moment when fusion of law and equity had the potential to unsettle the ancient jurisdictional patterns. Contrast agency, that other great repository of fiduciary law, which, having developed in the common law courts, was not disturbed by fusion. The substantially contemporaneous Restatement of Agency forthrightly articulates the contractarian character of the agency relationship. ${ }^{26}$

Scott's fear of fusion was probably exaggerated. He was, after all, strongly predisposed to resist the contractarian account of the trust. But taking his concern about fusion at face value, experience has shown that the danger is past. Two generations later, with the place of jury-free equitable jurisdiction over trusts now secure in our fused civil procedure, ${ }^{127}$ we can safely acknowledge the contractarian character of the modern trust. In the next part of this Article, discussing the functional correspondence of trust and contract, I point out that contractarian analysis actually reinforces the jury-free character

122. RESTATEMENT (SECOND) OF TRUSTS $\S 197 \mathrm{cmt}$. b (1959) (carrying forward language from RESTATEMENT (FIRST) OF TRUSTS $\S 197 \mathrm{cmt} . \mathrm{b}(1935)$ ).

123. Id.

124. Id.

125. Id.

126. "Agency is the fiduciary relation which results from the manifestation of consent by one person to another that the other shall act on his behalf and subject to his control, and consent by the other so to act." RESTATEMENT (SECOND) OF AGENCY \& 1.1 (1957) (substantially carrying forward language from RESTATEMENT (FIRST) OF AGENCY $\$ 1.1$ (1933)).

127. Although the overwhelming weight of American authority is that trust disputes are tried to a judge sitting without a jury, it can still happen that some court misunderstands or misapplies the law/equity division. For example, in Levinson v. Citizens Nat'l Bank, 644 N.E.2d 1264, 1267 (Ind. Ct. App. 1994), the court reasoned that since the trust beneficiaries sought damages for breach of trust, and damages are a characteristic common law remedy, the breach of trust action sounded in law rather than in equity, and the beneficiaries were entitled to demand jury trial. 
of the trust. Jury waiver is part of the default law of trusts, and is thus supported through the trust deal.

\section{THE FunCtional CORRESPONDENCE OF TRUST AND CONTRACT}

The contractarian account arises from two fundamental attributes of the trust. First, what I have been calling the trust deal, the deal between settlor and trustee that creates the trust, is voluntary. No one can be made to accept a trusteeship. ${ }^{128}$ Thus, the trust, like the contract, is a consensual juridical relationship. This feature has been present from the formative epoch and is what led Maitland to see the trust as a species of contract. ${ }^{129}$

The other contractarian feature is that virtually all trust law is default law-rules that the parties can reject. The rules of trust law apply only when the trust instrument does not supply contrary terms. ${ }^{130}$ Because the parties can oust the trust default regime, we say that they choose it by deciding not to oust it. The default character of trust law has become more insistent in modern times, as the trust has lost its connection to the relatively inflexible patterns of conveyancing, and as trust assets and trust purposes have become more variable.

These two traits, consensual formation and party autonomy over the terms, are the defining characteristics of the law of contract.

As in contract, so in trust, the autonomy of the parties is not wholly unrestrained. There are the obvious public policy prohibitions against trusts for illegal purposes. ${ }^{131}$ There are the traditional definitional minima-there must be trust property and beneficiaries capable of enforcing the trust. ${ }^{132}$ Furthermore, any branch of the law of gratuitous transfers requires anti-deadhand measures-in trusts, the rule against perpetuities ${ }^{133}$ and the implicit

128. "[T]he trustee is not under a duty to administer the trust unless he accepts." RESTATEMENT (SECOND) OF TRUSTS $\$ 169 \mathrm{cmt}$. a (1959). I exclude the constructive trust, a remedial device distinct from the ordinary law of trusts, see supra text accompanying notes 27-29.

129. See supra text accompanying notes $97-101$.

130. RESTATEMENT (SECOND) OF TRUSTS $\$ 164(a)$ (1959).

131. See id. $\$ \$ 60-62$.

132. "A trust cannot be created unless there is trust property of such a nature as to be the proper subject of a trust, and a proper beneficiary." Id. $\S 66$. "A trust cannot be created unless there is trust property." Id. $\S 74$. A trust is not valid "unless there is a beneficiary who is definitely ascertained at the time of the creation of the trust or definitely ascertainable within the period of the rule against perpetuities." Id. $\S 112$.

133. The Uniform Act is the version most widely in force. UNIF. STATUTORY RULE AGAINST PERPETUITIES WITH 1990 AMENDS., 8B U.L.A. 321 (1990). The point is asserted, but on slender authority, that the rule against perpetuities does not apply to contracts:

Owing to its roots as a means by which to curb remotely vesting future interests that made property inalienable, especially indestructible executory interests, the Rule Against Perpetuities is inapplicable to legal relationships that do not create property interests. Contracts-even long term contracts-are generally exempt. It has been held that optional modes of settlement for the payment of life insurance proceeds cannot violate the Rule, nor can annuity contracts, even though future payments may be subject to uncertainties that might not be resolved within a life in being plus 21 years. 
norm that the trust must be for the benefit of the beneficiaries. ${ }^{134}$ There are also limits on self-serving exculpation clauses in trust ${ }^{135}$ that echo the unconscionability protections in contract. ${ }^{136}$ Thus, in trust as in contract, the courts will intervene against market failure. But these limits hardly pinch in ordinary circumstances, and thus, in virtually any case, the entire terrain of trust law is default law.

The typical trust deal consists of a mix of terms, some drafted for the particular instrument, some taken from the drafter's form books or office forms, and some supplied by default law. Drafters vary in the propensity to absorb default law into the trust instrument; some drafters replicate a lot of default law, others draft only to defeat unwanted default law. Although the trust deal originates in a contract between settlor and trustee, they seldom haggle over terms. The trustee is normally indifferent to the distributive provisions. ${ }^{137} \mathrm{~A}$ corporate trustee will insist on its fee schedule, and it will insist on acceptable administrative provisions, but drafters know this and usually oblige in advance. Haggling over terms is not the test for whether relations are contractual; most contracts involve relatively little haggling. The

Lawrence W. Waggoner et al., Family Property Law 1080 (1991) (citing Doyle v. Massachusetts Mut. Life Ins. Co., 377 F.2d 19 (6th Cir. 1967) and Holmes v. John Hancock Mut. Life Ins. Co., 41 N.E.2d 909 (N.Y. 1942)). The opposite view seems equally plausible, that the concern to limit dead-hand restraints ought not to turn on the mechanics of the property/contract distinction.

134. The deviation doctrine, RESTATEMENT (SECOND) OF TRUSTS $\S 167$ (1959), authorizes the court to direct the trustee to depart from the terms of the trust in circumstances that the settlor had not anticipated "if necessary to carry out the purposes of the trust." Id. § 167(1). The leading case is In re Pulitzer's Estate, 249 N.Y.S. 87 (Sur. Ct. 1931), aff'd mem., 260 N.Y.S. 975 (Sup. Ct. 1932), in which the trust instrument forbade the sale of a certain newspaper. The paper became unprofitable, and the trustees sought and received judicial approval to sell it. I have no doubt that if the trust instrument in Pulitzer had foreseen and recited the danger that the paper might become unprofitable, and had directed retention of the investment in any event, the court would nevertheless have directed sale. If the settlor directs an objectively stupid investment policy, the court will direct deviation even though the settlor anticipates the circumstance. E.g., Colonial Trust Co. v. Brown, 135 A. 555, 564 (Conn. 1926) (voiding certain restrictions limiting the height of buildings to be erected on trust real estate in part because "the restrictions are opposed to the interests of the beneficiaries of the trust"). The settlor is presumed to intend to benefit the beneficiaries, but if it can be shown that a trust term manifestly harms their interests, deviation will be ordered. A private trust must be for the benefit of the beneficiaries.

Observe that garden-variety deviation from trust terms in unforeseen circumstances under Restatement (Second) of Trusts $\$ 167$ parallels contract-law relief for impossibility or frustration. See RESTATEMENT (SECOND) OF CONTRACTS $\$ \$ 261,265-66$ (1981).

135. RESTATEMENT (SECOND) OF TRUSTS $\$ 222(2)$ (1959) (stating that exculpation clause "is not effective to relieve the trustee of liability for breach of trust committed in bad faith or intentionally or with reckless indifference to the interest of the beneficiary, or of liability for any profit which the trustee has derived from a breach of trust").

136. See RESTATEMENT (SECOND) OF CONTRACTS $\$ 178$ (1981). Because the trust deal originates in a gift, a unilateral transfer, the concerns about information cost and market failure that motivate unconscionability limits on party autonomy for exchange transactions in contract law have less sway in trusts. However, within the sphere of the trust deal these concerns are present; RESTATEMENT (SECOND) OF TRUSTS $\$ 222(3)$ (1959), for example, refuses to enforce an exculpation clause that has been "inserted in the trust instrument as the result of an abuse by the trustee of a fiduciary or confidential relationship to the settlor."

137. Some institutional trustees resist dispositive powers that are highly discretionary, or that impose on the trustee the responsibility for investigating the needs and financial circumstances of the beneficiaries. 
test for contract, which the trust so easily satisfies, is consensual formation and consensual terms. ${ }^{138}$

A key distinction between contract and gift is the standard of intention that governs the transaction. A donative transfer is commonly said to be unilateral, and accordingly, only the donor's intent, ${ }^{139}$ not the donee's, is relevant to ascertaining the validity and terms of the transfer. In the world of the exchange transaction, by contrast, the intentions of both parties bear on the creation and the meaning of their deal. ${ }^{140}$ The private trust is a donative transfer, a means of making a gift. I have emphasized, however, that the gift in trust takes the form of a deal, between settlor and trustee, about how the trustee will manage and apply the trust assets for the benefit of the beneficiaries. Which standard of intention applies, that for gifts or for deals?

The answer is straightforward and turns on the question, which feature of the trust is in issue? The traditional answer, which is usually correct but sometimes oversimplified, is that the settlor's intention governs the meaning of the trust. ${ }^{141}$ The other party to the trust deal, the trustee, is indifferent to most of the contents of the trust. Fundamental terms that define the purposes of the trust, such as the choice of beneficiaries and the allocation of shares, have no effect on the interests of the trustee. Accordingly, only the settlor's intention governs. However, aspects of the trust deal that touch the interests, duties, and responsibilities of the trustee are bilateral concerns that import the contract norm of ascertaining the intentions of both parties. On such matters, the trustee's reasonable understanding of the deal should be as relevant as the settlor's.

In the discussion that follows, relating trust to contract, I notice tendencies toward convergence in aspects of contemporary trust and contract doctrine. I devote particular attention to the contractarian character of trust fiduciary law. I observe that the default regime of trust law can be understood as comprising a type of specialized contract. Acknowledging the contractarian basis of the law of trusts will sometimes improve outcomes, and I point to some examples.

\section{A. Converging Trends in Contract and Trust Law}

Prominent trends in modern contract law are making it ever easier to account for the trust within the norms of contract. I need refer only briefly to these developments: (1) the routinization of specific performance; (2) the

138. I continue to exclude the declaration of trust from this account, as explained supra text accompanying note 5 .

139. "The controlling consideration in determining the meaning of a donative document is the donor's intention. The donor's intention is given effect to the maximum extent allowed by law." RESTATEMENT (THIRD) OF PROPERTY: DONATIVE TRANSFERS $\$ 10.1$ (Tentative Draft No. 1, 1995).

140. RESTATEMENT (SECOND) OF CONTRACTS \& 17(1) (1981) requires "mutual assent."

141. "A trust is created only if the settlor properly manifests an intention to create a trust." Restatement (Second) of Trusts $\$ 23$ (1959); accord, e.g., Cal. Prob. Code \$ 15,201 (West 1991). 
growing appreciation of relational contracting; and (3) the spread of the good faith requirement.

\section{Specific Performance}

For purposes of remedy, the Anglo-American law of contract has historically straddled the law/equity line. A contract claim sounded in law, but the specific remedies, in particular, specific performance and injunctive relief, were only available in equity. Specific relief was called extraordinary and required a showing that the common law remedy, usually damages, would be inadequate. ${ }^{142}$ Thus, the common law of contract emerged with a strong emphasis on damages as the presumptive mode of relief. The trust, by contrast, was the exclusive preserve of Chancery. Specific performance lay routinely against the trustee (and where needed, against transferees) to enforce the trust deal. ${ }^{143}$

Modern American contract law has undergone a reorientation in its attitude toward specific relief. The courts have relaxed the requirements for obtaining specific relief, ${ }^{144}$ and scholars have made the case for discarding the automatic preference for relief in damages. ${ }^{145}$ Accordingly, the remedial tradition of the trust with its ready facility for specific relief no longer distinguishes the trust importantly from contract law.

\section{Relational Contracting}

Classical contract law presupposed the one-shot deal, my money for your horse. The terms of such a contract can be more easily specified than the terms of a contract that contemplates a multistage and contingent set of obligations.

A major contribution of the past generation of scholarship in contract law has been the emphasis on relational contracting, ${ }^{146}$ and in particular, on the

142. I DOBBS, supra note 27 , § 2.5 , at $123-48$.

143. See RESTATEMENT (SECOND) OF TRUSTS $§ 199$ (a) (1959). The long association of the trust with conveyancing, that is, with the holding and transferring of unique parcels of freehold land, made the routine grant of specific relief congenial.

144. "Courts have escaped the rule [that specific relief is available only when damages are inadequate] by defining adequacy in such a way that damages are never an adequate substitute for plaintiff's loss. Thus, our law embodies a preference for specific relief if plaintiff wants it." Douglas Laycock, The Death of the Irreparable Injury Rule, 103 HARV. L. REV. 688, 691 (1990).

145. Damages undercompensate because of the difficulty of monetizing all the harms arising from breach. See Alan Schwartz, The Case for Specific Performance, 89 YALE L.J. 271 (1979). Opinion is more mixed regarding the availability of specific performance when the cost to the defendant would be disproportionate to the benefit to the plaintiff. See Laycock, supra note 144, at 749-52; Timothy J. Muris, Comment, The Costs of Freely Granting Specific Performance, 1982 DuKE L.J. 1053. However, this situation is unlikely to arise in cases involving enforcement of trusts.

146. A particularly valuable account is Alan Schwartz, Relational Contracts in the Courts: An Analysis of Incomplete Agreements and Judicial Strategies, 21 J. LEGAL STUD. 271 (1992). See also OLIVER E. WILliamison, THE EConomic INSTITUTIONS OF CAPITALISM 68-84 (1985); Ian R. Macneil, Contracts: 
special attributes of contracts of long duration. Good examples are "generic agency relationships, including distributorships, franchises, joint ventures, and employment contracts." ${ }^{147}$ Long duration and multistage complexity in a deal increase the difficulty of contracting with precision. "A contract is relational to the extent that the parties are incapable of reducing important terms of the arrangement to well-defined obligations." 148 The inability to specify terms of the relationship leads the parties to remit important steps to intrinsically discretionary future determinations, but that discretion risks the potential for opportunistic behavior. When a dispute arises, the court is asked to engage in "relational interpretation," for example, in a franchising case, "to identify the entirety of the commitment structure that underlies the franchise arrangement and then to enforce those commitments." 149

Most trusts are well understood as relational contracts. Outside commercial settings, ${ }^{150}$ a trust for a short-term purpose is rare. The normal trust contemplates long duration and considerable change of circumstances. Most trusts are measured in lives, that is, the trust terminates at the end of a particular life or group of lives. The discretion that is required to manage modern trust assets and, in some cases, to allocate beneficial shares (for example, when the instrument gives the trustee a power to invade corpus to increase a share in case of need) cannot be bounded at the outset of the trust. The sensitivity to relational contracting is, therefore, another point of convergence between modern contract law and the reality of the modern trust. ${ }^{151}$

\section{Good Faith}

Across the middle decades of the twentieth century, American law came to recognize a duty of good faith in contracting. The Restatement (Second) of

Adjustments of Long-Term Economic Relations under Classical, Neoclassical, and Relational Contract Law, 72 Nw. U. L. REV. 854 (1978).

147. Charles J. Goetz \& Robert E. Scott, Principles of Relational Contracts, 67 VA. L. Rev. 1089, 1091 (1981).

148. Id.

149. Gillian K. Hadfield, Problematic Relations: Franchising and the Law of Incomplete Contracts, 42 STAN. L. REV. 927, 983 (1990).

150. Which fall outside the themes of this Article. See supra text accompanying notes 19-24.

151. Goetz and Scott identify various "fiduciary" relations-including those involving attomeys, executors, and partners-that "are properly analyzed as relational contracts because they tend to be characterized by uncertainty about factual conditions during performance and an extraordinary degree of difficulty in describing specifically the desired adaptations to contingencies." Goetz \& Scott, supra note 147 , at 1127. Add trustees to their list of fiduciary relationships, and the quoted passage would well state the overlap between relational contracting and trust.

A major theme in the economic analysis of relational contracting is that the sources of incompleteness in such contracts vary, in ways that affect the appropriateness and character of judicial interpretation. See Schwartz, supra note 146 , at $273-81$. 
Contracts now provides: "Every contract imposes upon each party a duty of good faith and fair dealing in its performance and its enforcement."

Although expressed as an immutable contract term, the duty of good faith functions as an intention-implementing standard. Burton's study, emphasizing New York case law, found that the "courts generally do not use the good faith performance doctrine to override the agreement of the parties," but "to effectuate the intentions of the parties, or to protect their reasonable expectations, through interpretation and implication." 153 Courts use the good faith norm to regulate performance in cases in which the contract or the circumstances confer significant discretion on one party. The doctrine restricts the use of "discretion to recapture opportunities foregone ... on entering the contract."154 In the formulation of Easterbrook and Fischel, "The concept of the duty of good faith like the concept of fiduciary duty is a stab at approximating the terms the parties would have negotiated had they foreseen the circumstances that have given rise to their dispute."15s

The duty of good faith reinforces effective relational contracting, because it limits opportunistic abuse of discretion in those long-duration or otherwise multiphased contracts in which significant discretion in performance is unavoidable. The good faith standard in contract law echoes the norms of trust fiduciary law, which regulate the trustee's embedded discretion in performing the trust deal.

\section{B. Trust Fiduciary Law}

\section{The Duties of Loyalty and Prudence}

The law of fiduciary administration, the centerpiece of the modern law of trusts, resolves into two great principles, the duties of loyalty and prudence.

The duty of loyalty requires the trustee "to administer the trust solely in the interest of the beneficiary." 156 This obligation implements the beneficiaries' entitlement to the trust assets. The trustee owns the assets, but only to facilitate the beneficiaries' enjoyment. The loyalty norm forbids the trustee from self-dealing with trust assets and from engaging in conflict-ofinterest transactions adverse to the trust. ${ }^{157}$ The harshest application of the

152. REsTATEMENT (SECOND) OF CONTRACTS $\$ 205$ (1981).

153. Steven J. Burton, More on Good Faith Performance of a Contract: A Reply to Professor Summers, 69 IOWA L. REv. 497, 499 (1984).

154. Id. at 500 .

155. Frank H. Easterbrook \& Daniel R. Fischel, Contract and Fiduciary Duty, 36 J.L. \& EcoN. 425, 438 n.28 (1993).

156. RESTATEMENT (SECOND) OF TRUSTS $§ 170$ (1) (1959), continued in RESTATEMENT (THIRD) OF TRUSTS: PRUDENT INVESTOR RULE \$ 170(1) (1992). The 1992 volume does not republish the official comments, which remain in force in the 1959 edition.

157. For current treatise discussion, see BOGERT, TRUSTS, supra note $28, \S 543 ; 2$ A SCOTT \& FRATCHER, TRUSTS, supra note $3, \S \S 170-170.25$, at 311-437. 
duty of loyalty is prophylactic. The trustee who deals with trust property for the trustee's own account is liable to disgorge the profits to the trust even if the trustee paid fair value for the property. ${ }^{158}$ By contrast, for liability to arise from a breach of the requirements of prudent administration or prudent investing, the trustee's lapse must be shown to have caused harm.

The duty of prudent administration is a reasonableness norm, comparable to the reasonable person rule of tort. ${ }^{159}$ An objective standard of care places the trustee "under a duty to the beneficiary in administering the trust to exercise such care and skill as a man of ordinary prudence would exercise in dealing with his own property." 160 Subrules of fiduciary administration abound-for example, the duties to keep and render accounts, to furnish information, to invest or preserve trust assets and make them productive, to enforce and defend claims, to diversify investments, and to minimize costs. ${ }^{161}$ All these rules are subsumed under the duties of loyalty and prudence, they are means of vindicating the beneficial interest. ${ }^{162}$

Part II of this Article, explaining the historical transformation of the trust from a conveyancing device to a vehicle for the active management of financial assets, pointed to the immense discretion that has come to inhere in modern trust administration. Trust fiduciary law regulates the trustee's exercise of that discretion. ${ }^{163} \mathrm{Be}$ it in trust law or in other fields of fiduciary obligation (for example, corporations, agency, or partnership), fiduciary duties are default norms imposed in juridical relations that feature "scope for the exercise of discretion."164 Fiduciary duties mean to "induce the fiduciary to use his power beneficently."165

158. E.g., Hartman v. Hartle, 122 A. 615 (N.J. Ch. 1923).

159. The Uniform Prudent Investor Act says in its official comment:

The concept of prudence in the judicial opinions and legislation is essentially relational or comparative. It resembles in this respect the "reasonable person" rule of tort law. A prudent trustee behaves as other trustees similarly situated would behave. The standard is, therefore, objective rather than subjective.

UNIF. PRUDENT INVESTOR ACT $\$ 1$, cmt., 7B U.L.A. 16, 19 (1994).

160. RESTATEMENT (SECOND) OF TRUSTS $\$ 174$ (1959). The prudence norm as applied to investing and managing the trust assets appears in RESTATEMENT (THIRD) OF TRUSTS: PRUDENT INVESTOR RULE $\S$ 227 (1992).

161. RESTATEMENT (SECOND) OF TRUSTS $\$$ 172-78, 188 (1959); RESTATEMENT (THIRD) OF TRUSTS: PRUDENT INVESTOR RULE $\$ 227$ (b) (1992).

162. The duty of impartiality, requiring the trustee to act with due regard to the interests of all the beneficiaries when there are multiple beneficiaries, RESTATEMENT (SECOND) OF TRUSTS \$\$ 183, 232 (1959), is sometimes regarded as a separate norm of fiduciary law coordinate in stature with loyalty and prudence. In truth, the duty of impartiality is an application of the duty of loyalty. The trustee cannot act solely in the interest of the beneficiaries as required under the duty of loyalty without taking due regard of their competing interests. ERISA, the federal pension statute, neglected to codify the duty of impartiality when it made trust fiduciary law the statutory regime for pension trusts, but the federal courts derived the duty of impartiality from ERISA's duty of loyalty. LANGBEIN \& WOLK, supra note 21, at 650 .

163. On the sources of trustees' discretion and the appearance of fiduciary law in place of the older regime of restrictive trustees' powers law, see supra text accompanying notes 72-92.

164. Weinrib, supra note 120 , at 4 .

165. Id. at 5 . 
This combination of broad discretion in the trustee, coupled with fiduciary norms to protect the beneficiary against abuse of discretion, is a second-best solution to the problem of enforcing the trust deal. Ideally, as Cooter and Freedman observe, the deal between settlor and trustee would contain "specific rules that dictate how the fiduciary should manage the asset in the beneficiary's best interests." ${ }^{\text {"166 }}$ Alas, "the fiduciary's obligations are openended. Because asset management necessarily involves risk and uncertainty, the specific behavior of the fiduciary cannot be dictated in advance."167 Easterbrook and Fischel observe in a similar vein that "the duty of loyalty is a response to the impossibility of writing contracts completely specifying the parties' obligations."163

A crucial consideration in understanding why trustees, especially expert professional trustees such as corporate fiduciaries, willingly accept the potential liability of trust fiduciary law with every trust deal is that compliance with trust fiduciary law is ordinarily not onerous. The prudent investor rule is profoundly protective of trustees who have followed common investmentindustry standards. The duty of loyalty, though it threatens draconian prophylactic liabilities for breach, is also easy enough to obey in ordinary cases. It says to the trustee, "You are left with the entire universe of investment possibilities as outlets for your entrepreneurial impulses; you are required only to stay away from the trust assets when you seek your own fortune."

\section{The Contractarian Basis of Fiduciary Law}

Easterbrook and Fischel, emphasizing corporate law, explain why fiduciary law is contractarian. Their reasoning applies equally to trusts.

When the task is complex, when efforts will span a substantial time, . . . a detailed contract would be silly. When one party hires the other's knowledge and expertise, there is not much they can write down. Instead of specific undertakings, the agent [the manager in corporations, the trustee in the law of trusts] assumes a duty of loyalty in pursuit of the objective and a duty of care [prudence in the law of trusts] in performance. ... [T] he process is contractual-because both principal and agent enter this understanding for gain ....

166. Robert Cooter \& Bradley J. Freedman, The Fiduciary Relationship: Its Economic Character and Legal Consequences, 66 N.Y.U. L. REV. 1045, 1046 (1991).

167. Id. at 1046-47. Further: "If the parties to this agreement possessed perfect information, disloyalty could be controlled or prevented by contract. In fiduciary relationships, however, the parties are unable to foresee the conditions" necessary to spell out the optimum steps by contract. Id. at 1048 .

168. Easterbrook \& Fischel, supra note 155, at 426. 
... [A] "fiduciary" relation is a contractual one characterized by unusually high costs of specification and monitoring. The duty of loyalty replaces detailed contractual terms . . . ${ }^{169}$

Loyalty and prudence, the norms of trust fiduciary law, embody the default regime that the parties to the trust deal would choose as the criteria for regulating the trustee's behavior in these settings in which it is impractical to foresee precise circumstances and to specify more exact terms.

The theme that fiduciary law is prevailingly contractarian has not been much appreciated in trust or other fiduciary law. Two reasons suggest themselves, the rhetorical tradition of fiduciary law and the somewhat scattered way in which the contractarian principle has been organized and expressed in legal doctrine.

Breach of fiduciary duty can be an ugly sight-visualize the widow and orphans left destitute because the trustee looted the trust fund. Courts naturally use moralistic language to describe such behavior. Easterbrook and Fischel are too dismissive when they say, "Fiduciary duties ... have no moral footing; they are the same sort of obligations, derived and enforced in the same way, as other contractual undertakings." 170 Even though fiduciary duties are contractually assumed, they embody deep moral precepts about the behavior appropriate for a trustee or other fiduciary. But Easterbrook and Fischel are quite correct to deprecate the rhetorical excesses of fiduciary law, exemplified in Cardozo's incessantly cited opinion in Meinhard v. Salmon. ${ }^{171}$ Courts sermonize about fiduciary duties without paying adequate attention to the question of whether and why the particular person is a fiduciary and what standards the fiduciary relationship imports in the particular circumstances. ${ }^{172}$ When an indignant court follows Cardozo and limits its analysis to sounding off about fiduciary standards being "stricter than the morals of the market place" and "the punctilio of an honor the most sensitive," 173 the court is neglecting to discuss whether the underlying deal supports the level of fiduciary obligation that the court invokes.

The other attribute of trust fiduciary law that has tended to conceal its contractarian character is the scattered way that the contractarian principle has been articulated in trust doctrine. Contract is there, but not always at first glance. Turn to the Restatement of Trusts for the formulation of the duty of

169. Id. at $426-27$.

170. Id. at 427 .

171. 164 N.E. 545 (N.Y. 1928). Posner calls Meinhard v. Salmon "[t]he most famous of Cardozo's moralistic opinions." RICHARD A. POSNER, CARDOZO: A STUDY IN REPUTATION 104 (1990). At the time Posner wrote, the case had attracted 653 subsequent citations. Id. at 105.

172. Meinhard v. Salmon was a 4-3 decision about the uncertain responsibilities of joint venturers following the conclusion of a 20 -year lease on a hotel. The dissent construed the deal differently and would have exonerated the defendant. See 164 N.E. at 551-52 (Andrews, J., dissenting).

173. Id. at 546 . 
loyalty in section 170(1), and you find no talk of deals. "The trustee is under a duty to the beneficiary to administer the trust solely in the interest of the beneficiary."174 A novice could be excused for thinking that section 170(1) propounds an immutable rule, a rule that the parties cannot alter. Look again, however, and the contractarian standard emerges. Comment $t$ propounds the authorization doctrine, under which the settlor is invited to use the trust instrument that embodies the trust deal to overturn the duty of loyalty:

By the terms of the trust the trustee may be permitted to sell trust property to himself individually, or as trustee to purchase property from himself individually, or to lend to himself money held by him in trust, or otherwise to deal with the trust property on his own account. ${ }^{175}$

In other words, the duty of loyalty is default law that yields to contrary terms of the trust deal. ${ }^{176}$

Numerous Restatement examples illustrate the prevalence of authorization over default rules. For example: "A bank or trust company as trustee cannot properly purchase for the trust its own shares, even though they are purchased from third persons," but this disloyal transaction is allowed when "expressly or impliedly authorized by the terms of the trust." exhibits this tendency to articulate the duty of loyalty sweepingly, while voicing more circumspectly or as a defense the authorization doctrine that remits the scope of the duty to party autonomy. ${ }^{178}$ But these are matters of tone, not substance. Express terms dominate default rules in fiduciary law, as they do in the rest of trust law.

The authorities reformulating the duty of prudent investing-the Restatement (Third) of Trusts: Prudent Investor Rule of $1992^{179}$ and the

174. RESTATEMENT (SECOND) OF TRUSTS $§ 170(1)$ (1959).

175. Id. $\$ 170(1) \mathrm{cmt} . \mathrm{t}$ (1959). The quoted passage continues: "The trustee violates his duty to the beneficiary, however, if he acts in bad faith, no matter how broad may be the provisions of the terms of the trust in conferring power upon him to deal with the trust property on his own account." Id. This proviso is intent-implementing, forbidding the trustee to invoke nominally permissive language in circumstances that are outside the purposes of the trust deal.

176. Characteristic decisional authority on the point includes In re Estate of Halas, 568 N.E.2d 170, 178 (Ill. App. Ct. 1991); In re Krause's Estate, 172 N.W.2d 468, 470-72 (Mich. Ct. App. 1969); Estate of McCredy, 470 A.2d 585, 596-601 (Pa. Super. Ct. 1983). See generally J.D. Perovich, Annotation, Validity and Construction of Trust Provision Authorizing Trustee to Purchase Trust Property, 39 A.L.R.3d 836 (1971).

Easterbrook and Fischel say: "Nothing illustrates the contractual character of fiduciary law better than one of the comerstones of trust law: an express provision in the trust instrument governs over the duty of loyalty in the event of conflict." Easterbrook \& Fischel, supra note 155, at 429 (citing RESTATEMENT (SECOND) OF TRUSTS $\$ 222$ (1959), the provision that permits the trust instrument to contain an exculpation clause).

177. Restatement (SECOND) OF TRUSTS $\$ 170 \mathrm{cmt}$. n (1959).

178. E.g., Rosencrans v. Fry, 95 A.2d 905, 912-13 (N.J. 1953).

179. RESTATEMENT (THIRD) OF TRUSTS: PRUDENT INVESTOR RULE $\$ 228(\mathrm{~b})$ (1992) subjects the trustee to the duty "to conform to the terms of the trust directing or restricting investments by the trustee," as well 
Uniform Prudent Investor Act of 1994-have been drafted more recently, and they forthrightly integrate the authorization doctrine into the duty. The Uniform Act says: "The prudent investor rule, a default rule, may be expanded, restricted, eliminated, or otherwise altered by the provisions of a trust." ${ }^{180}$ Explicit deal trumps default regime.

Another fundamentally contractarian reinforcement for the conventional duties of loyalty and prudence is the rule that the beneficiary may consent to trustee behavior that would otherwise breach these duties. ${ }^{181}$

\section{Trust as a Standardized Contract ${ }^{182}$}

Having seen that trusts are deals, and that contract accounts well for trust, we can view trust default law in functional terms as a type of standardized contract. The contract terms are well known to transaction planners and exceptionally easy to invoke.

By calling their deal a trust, ${ }^{183}$ the parties automatically incorporate an extensive body of default terms that have proven highly suitable for implementing deals of this type. The contractarian account views the parties as choosing this default regime for their particular deal, except to the extent they modify it.

\section{Management Regime}

I have emphasized that the modern trust is preeminently a management device for separating ownership and enjoyment; the trust deal sets the terms under which the trustee administers and applies the assets.

Unless modified or ousted, several blocks of trust default law define this relationship. Trustees' powers legislation authorizes transacting, fiduciary law regulates the purposes and standards of transacting. The default managerial regime also sets trustee compensation.

On all these matters the default regime impounds the experience of decades of trust practice, legislation, and case law. The transaction planner

as to any mandatory investment requirements of a governing statute. Section 227 (d) makes it explicit that $\S 228$ (b) overrides the prudent investor norms of $\$ 227$. Id. $\$ 227$ (d).

180. UNIF. PRUDENT INVESTOR ACT § 1(b), 7B U.L.A. 18 (1994). The official comment says: "Almost all of the rules of trust law are default rules, that is, rules that the settlor may alter or abrogate. Subsection [1(b)] carries forward this traditional attribute of trust law." 1 . $\$ 1(b) \mathrm{cmt}$.

181. RESTATEMENT (SECOND) OF TRUSTS $\$ 170 \mathrm{cmt} . \mathrm{w}, \S 216$ (1959).

182. Hansmann and Mattei develop in a forthcoming paper the theme that the trust "offers a standard form" for "contractual relationships." Henry Hansmann \& Ugo Mattei, The Comparative Law and Economics of Private Trusts 18 (Sept. 1995) (unpublished manuscript, on file with author). Greely relates the literature on form contracts to aspects of property law in Henry T. Greely, Contracts as Commodities: The Influence of Secondary Purchasers on the Form of Contracts, 42 VAND. L. REV. 133 (1989).

183. No words of art are required to invoke the trust regime, see RESTATEMENT (SECOND) OF TRUSTS $\S 24(2)$ (1959), but a competent drafter taking maximum advantage of the efficiency of the trust as standardized regime does not leave the court to wonder whether a trust was intended. 
who invokes the default regime is spared the difficulty, uncertainty, and expense of attempting to design afresh a management regime capable of anticipating the imponderables that the future holds in store for the trust beneficiaries and the trust assets.

\section{Regime for Multiple and Successive Interests}

When likening trusts to relational contracts, I observed that trusts commonly envision relationships of long and uncertain duration, usually measured in lives. Trusts almost invariably provide for several beneficiaries, often contingently, often in succession (for example, my widow for life, then my children, but should any child predecease my widow leaving issue, then the predeceased child's share to such issue). Trusts can endure for decades.

Trust default law is sensitive to the problems of ascertaining multiple and successive beneficial interests, and of administering the trust for them. Trust law absorbs from the underlying property law both the system of future interests, ${ }^{184}$ including powers of appointment, and the set of constructional principles that identify the appropriate shares under class terminology. ${ }^{185}$ The duty of impartiality ${ }^{186}$ requires the trustee to give due regard to the interests of all the beneficiaries. Legislation such as the Uniform Principal and Income Act $^{187}$ applies the duty of impartiality to the quirks of various assets, allocating receipts and expenses among the several interests. The virtual representation principle allows the current generation to stand in for unborns. $^{188}$ The rule permitting modification of trusts ${ }^{189}$ in changed circumstances also responds to the multiplicity and long duration of successive trust interests; the aspiration is to carry out the trust deal as the parties would have wanted had they been able to foresee the changed circumstances.

Because human foresight is so limited when projected across future generations, the trust default regime for these matters is hard to improve upon. Hence, most drafters prefer to accept most of it rather than attempt to better it.

184. The law of future interests arose in connection with legal estates, but in modern practice the competent drafter invariably insists on creating future interests only in trust property, in order that the managerial prowess of the trust be brought to bear on the coordination problems that can arise with multiple interests in common property. For a succinct account of the virtues of placing such interests in trust, see JeSSE DUKEMINIER \& STANLEY M. JOHANSON, Wills, TRUSTS \& ESTATES 572-75 (5th ed. 1995). In England, the 1925 legislation effectively mandates the trust for such interests. Id. at 575 .

185. The modern American law on powers of appointment and class gifts appears in RESTATEMENT (SECOND) OF PROPERTY: DONATIVE TRANSFERS \$\$ 11.1-30.2 (1992).

186. RESTATEMENT (SECOND) OF TRUSTS $\$ \$ 183,232$ (1959), discussed supra note 162.

187. The current version, UNIF. PRINCIPAL \& INCOME ACT, 7B U.L.A. 145 (1962), is being redrafted by the Uniform Law Commission for projected approval in 1997.

188. E.g., UNIF. PROBATE CODE § 1-403, 8 U.L.A. 49 (1990),

189. RESTATEMENT (SECOND) OF TRUSTS §\$ 335-36 (1959). 


\section{Procedural Regime}

The trust default regime also comes equipped with a procedural package for implementing the trust deal. Trust procedure law may be described as a three-tier structure. The routine phase is periodic judicial accounting. ${ }^{190}$ The accounting informs the beneficiaries, enabling them to enforce their rights. The accounting also provides closure for trustees on current installments of these long-duration undertakings. Because, however, judicial accountings can be costly and clumsy, drafters sometimes prefer to alter the default regime in favor of nonjudicial accountings. ${ }^{191}$

The second procedural level, for situations of uncertainty or dispute, is judicial instruction. The trust tradition has been precocious in allowing the parties, typically the trustee, early resort to authoritative judicial guidance. ${ }^{192}$

Finally, if litigation arises, it is tried to the judge, sitting without a jury.

There is nothing novel in contracts that expressly design procedural measures, for example, forum selection clauses or arbitration clauses, or clauses that waive jury trial. From the contractarian perspective we understand the attractive procedural package of the trust default regime as a set of measures that the parties to the trust deal (the settlor and the trustee) elect when they couch their deal as trust.

Recall Scott's concern that acknowledging the contractarian basis of the law of trusts might undercut the traditional preference for nonjury trial of trust litigation, since jury trial is the default norm for ordinary contracts. ${ }^{193}$ In truth, the contractarian account of the trust reinforces the nonjury tradition of the trust, by treating the trust as a type of specialized contract in which the parties presumptively agree upon nonjury adjudication as the default term. Far from undercutting the traditional preference for nonjury trial in trust matters, the contractarian account of the trust strengthens that preference by recognizing the parties' autonomy to prefer it for their deal.

Certain distinctive remedial devices should also be seen as belonging to the procedural regime of the trust, including the court's powers to remove a trustee for cause ${ }^{194}$ and to reduce or deny compensation to a trustee who breaches the trust. ${ }^{195}$

190. Id. § 172 (1959).

191. See David Westfall, Nonjudicial Settlements of Trustees' Accounts, 71 HARV. L. REV. 40 (1957).

192. RESTATEMENT (SECOND) OF TRUSTS $\$ 259$ (1959); BOGERT, TRUSTS, supra note 28, 559.

193. See supra text accompanying notes 122-26.

194. See RESTATEMENT (SECOND) OF TRUSTS $\S 107 \mathrm{cmts}$. a, b (1959).

195. Id. § 243. 


\section{Statutory Trusts}

Another indication that the trust has something of the function of a standardized-type contract is the easy tendency for lawmakers to mandate the trust in a variety of settings in which certain of its attributes-typically the separation of management from enjoyment and the fiduciary regime for controlling managerial discretion-make the trust form a convenient solution to some perceived problem. Examples range from such public law devices as the Social Security trust funds ${ }^{196}$ and state workers' compensation trust funds $s^{197}$ to the regulatory systems that require union-dominated employee benefit funds ${ }^{198}$ and private pension plans ${ }^{199}$ to utilize the trust form. Like the standardized contract that the drafter pulls down from the shelf of form books, the trust is a ready regime for the legislator to invoke when dealing with the recurrent and intrinsically risky situation of managers having discretion over somebody else's money. ${ }^{200}$

\section{Altering Outcomes}

Because contract is simply an alternative doctrinal rubric for describing what our law achieves with the trust, the outcomes under contractarian analysis ought not to differ in most respects from those already current in trust law. The principal gain is candor. There are, however, some problem spots in the law of trusts, places in which greater attention to the contractarian basis of the trust should affect outcomes. The contractarian premise is that the law should

196. 42 U.S.C. \$ 401 (1991).

197. See BOGERT, TRUSTS, supra note $28, \S 246$.

198. Taft-Hartley Act $\S 302(c)(5), 29$ U.S.C. $\$ 186(c)(5)(1988)$.

199. Employee Retirement Income Security Act (ERISA) § 403, 29 U.S.C. $\$ 1053$ (1988).

200. I have elsewhere pointed out, speaking of ERISA, that these transferred usages of the trust can be problematic when the statutory design neglects to adjust for the differences between a trust deal that implements a gratuitous transfer and a trust deal that is part of an exchange transaction.

The insight that ERISA's drafters failed to capture in their fiduciary law is that in the ERISA pension trust the nominal trust beneficiaries (that is, the plan participants and their beneficiaries) are seldom at risk [because the Pension Benefit Guaranty Corporation (PBGC) guarantees most defined benefit pension promises, with full recourse against the employer]; accordingly, the fiduciary rules should have been more concerned to protect the employer's stockholders and the PBGC than the plan participants.

John H. Langbein, The Conundrum of Fiduciary Investing under ERISA, in PROXY VOTING OF PENSION PLAN EQUITY SECURTTIES 128, 133 (Dan M. McGill ed., 1989) (Pension Research Council, Wharton School). This theme is developed in Daniel Fischel \& John H. Langbein, ERISA's Fundamental Contradiction: The Exclusive Benefit Rule, 55 U. CHI. L. REv. 1105 (1988).

For regulatory reasons ERISA greatly limits the parties' autonomy to contract around ERISA fiduciary law. The Supreme Court has construed ERISA \$ 404(a)(1)(D), 29 U.S.C. \$ 1104(a)(1)(D) (1988), to mean "that trust documents cannot excuse trustees from their duties under ERISA." Central States, Southeast \& Southwest Areas Pension Fund v. Central Transp., Inc., 472 U.S. 559, 568 (1985). Despite this provision, the courts have recognized an important sphere for contractual autonomy by identifying certain intrinsic "business" or "settlor" functions that the courts treat as falling outside the reach of ERISA's mandatory fiduciary law. These include the powers to offer, enrich, or terminate an ERISA-covered plan. See LANGBEIN \& WOLK, supra note 21 , at 635-36, 819-20, 897. 
strive to implement the trust deal, the deal between settlor and trustee. I offer two examples of situations in which traditional trust law has not given enough weight to the deal.

\section{Standing: Settlor Enforcement}

The present default rule governing standing to enforce a trust excludes the settlor. In the words of the second Restatement, only the "beneficiary or one suing on his behalf can maintain a suit against the trustee to enforce the trust," ${ }^{201}$ The official comment to the Restatement observes revealingly that contract could reverse this rule:

[I]f the settlor makes a contract with the trustee, he can maintain an action on the contract against the trustee. The trustee, however, merely by accepting the trust and agreeing to perform his duties as trustee does not make a contract with the settlor to perform the trust which the settlor could enforce. ${ }^{202}$

Starting from its recurrent false premise that trusts are not contracts, the Restatement concludes in this passage that a separate contract beyond the trust would be needed to create a power in the settlor to enforce the trust. The trust default regime has no room for settlor enforcement, the Restatement reasons, because the settlor of a trust retains no right in the trust property ${ }^{203} \mathrm{We}$ see, therefore, that the Restatement rule rests on the familiar tautology. Since trust is a property relationship, the settlor who no longer owns the property cannot enforce the trust.

Admit the contractarian basis of the trust, however, and the case for reversing the default rule has been opened. The proper question becomes: What was the intention of the parties to the trust deal respecting this point, and if they did not articulate their intention on this matter, which default rule captures the likely bargain they would have struck had they thought about it? When such an intention-seeking standard is applied, as it is, for example, to third-party-beneficiary contracts, the parties are routinely assumed to have intended enforcement by the promisee (the settlor-equivalent person) as well as the beneficiary. ${ }^{204}$

201. Restatement (SECOND) of TRusts $\$ 200$ (1959). Case law is collected in 3 ScotT \& FRATCHER, TRUSTS, supra note 3, \$ 200.1, at 211-12 n.2. See also Note, Right of a Settlor to Enforce a Private Trust. 62 HARV. L. REV. 1370 (1949) (criticizing rule of nonenforcement on contractarian grounds). But see John T. Gaubatz, Grantor Enforcement of Trusts: Standing in One Private Law Setting, 62 N.C. L. REV. 905, 911 (1984) (expressing distrust of contractarian analysis because of difficulty of ascertaining "when the underlying contract exists").

202. RESTATEMENT (SECOND) OF TRUSTS $\$ 200 \mathrm{cmt}$. b (1959).

203. "Where, however, the settlor retains an interest in the trust property, he can of course maintain a suit against the trustee to protect that interest." Id.

204. See RESTATEMENT (SECOND) OF CONTRACTS $\$$ 305, 307 (1981). 


\section{Embedded Conflicts of Interest}

Greater sensitivity to the expectations of the parties to the trust deal can protect the legitimate interests of the trustee as well as those of the settlor. I take as my example the duty of loyalty, which, it will be recalled, forbids the trustee both from self-dealing with trust property and from conflict-of-interest transactions in which the trustee derives personal advantage from managing the trust property. ${ }^{205}$ We have seen why the duty of loyalty is a presumptively contractarian norm, embodying a prophylactic rule that can fairly be imputed as the default regime that the parties would have chosen had they thought about it. We have seen that, although the duty of loyalty is harsh-a penal deterrent rule that imposes liability even when loss has not resulted - compliance with the prohibition against self-dealing is ordinarily not burdensome, because the trustee is forbidden only one tiny sliver of the world of investment opportunities, namely, the assets in the trust.

The duty of loyalty works smoothly enough in garden-variety self-dealing situations. Trustees stand well warned, and they virtually always obey the rule against self-dealing. When, however, a trustee is discovered to have yielded to the temptation to buy a trust asset or to sell a personal asset to the trust, the liability arises and disgorgement of gain follows. In "mere" conflict-of-interest settings, by contrast, the duty of loyalty has not been such an unambiguous success story. The rule is overbroad, especially in situations involving personal as opposed to institutional trustees. Conflicts of interest are sometimes embedded in the very relationship that induces the settlor to ask the particular individual to serve as trustee.

Consider the leading American case, In re Rothko ${ }^{206}$ (which involved executors $^{207}$ rather than trustees). The New York Court of Appeals held that two of three coexecutors whom Mark Rothko selected to administer his estate had a conflict of interest in the transactions by which the estate sold Rothko's paintings to the Marlborough Gallery. ${ }^{208}$ One of the executors, Reis, was a director of the Marlborough. Another executor, Stamos, was an artist whom Marlborough represented. After the prices of Rothko paintings appreciated dramatically, the courts imposed draconian liabilities for the supposed shortfall upon the two fiduciaries, assertedly on account of their conflicts of interest. ${ }^{209}$

205. See supra text accompanying notes 156-58.

206. 372 N.E.2d 291 (N.Y. 1977).

207. See supra text accompanying note 57 for discussion of correspondence of trusteeship and executorship.

208. Rothko, 372 N.E.2d at 296.

209. Id. at $298,300$. 
Richard Wellman has criticized this dimension of Rothko in a prominent article. ${ }^{210} \mathrm{He}$ observed that Mark Rothko personally selected Marlborough as the gallery through which he sold his paintings during his lifetime. ${ }^{211}$ Wellman further noted, "Rothko knew that Reis and Stamos had personal ties to the gallery. These facts suggest that Rothko wanted his executors to deal with the gallery."212

The factors that Wellman addressed and that the New York Court of Appeals disregarded are essentially contractarian. What was the logic of the parties' deal? Did the two executors provoke a disloyal conflict, or did they pursue a course of action that Rothko tacitly authorized when he selected fiduciaries who came with an embedded conflict? At this distance from the litigation, these questions that the court did not ventilate are hard to answer. If, however, the contractarian basis of the trust deal (in this case, an estate deal) were understood, questions of this sort would be properly posed and investigated. Family and personal trustees often have interests adverse to the trust. The settlor's determination to ask these conflicted persons to serve bears materially on the standard of fiduciary duty that the trust deal embodies.

Readers familiar with the modern English law will see that contractarian analysis would bear on the leading case of Boardman v. Phipps, ${ }^{213}$ which has caused much disquiet. The trust owned a block of just over a quarter of the shares of what Americans would call a close corporation. The defendants, a trustee and an entrepreneur, developed a plan to reorganize the firm and enhance shareholder values. The trust declined to buy the additional shares needed to make the scheme work. Using information acquired while representing the trust, the defendants bought additional shares for themselves to force the reorganization. The plan succeeded, and the value of the trust's shares increased substantially. The defendants profited on the shares that they had purchased for themselves to make the plan work. A divided House of Lords held the defendants liable to disgorge to the trust their profit on these personally acquired shares, although the court allowed the defendants liberal compensation for their services.

Using the hypothetical bargain analysis of contract, the question is whether, had the settlor anticipated the opportunity to make the trust better off by allowing the fiduciaries to become co-venturers in such a situation, he would have authorized the step. Manifestly, the well-counselled fiduciary

210. Richard V. Wellman, Punitive Surcharges Against Disloyal Fiduciaries-Is Rothko Right?, 77 MICH. L. REV. 95 (1978).

211. See id. at 114 n.68.

212. Id. at 113. Wellman also pointed out that Reis's financial gain as a Marlborough director was trivial. Id. at 113 n.67. Further, "much of ... [Marlborough's profit on reselling the Rothko paintings] was generated by the gallery's vigorous promotion and by publicity from the litigation." Id. at 114 .

213. Boardman v. Phipps, [1967] 2 App. Cas. 46 (H.L.), aff'g Phipps v. Boardman, [1965] Ch. 992. For a succinct account of the facts and the opinions, see Gareth Jones, Unjust Enrichment and the Fiduciary's Duty of Loyalty, 84 LAW Q. REv. 472, 481-86 (1968). 
situated as were the defendants in Boardman v. Phipps should seek judicial instruction in advance of engaging in a conflict-tainted transaction. But amateurs are not always alert to the wisdom of that step. Indeed, in Rothko the executors were mistakenly advised by counsel that advance judicial instruction would not have been available. ${ }^{214}$

The prophylactic duty of loyalty presses too harshly on trustees and comparable fiduciaries in settings such as Rothko and Boardman v. Phipps. Low-grade conflicts of interest are especially endemic in family trusteeships. We see constantly in real-world practice some version of the case in which my father names me trustee for my mother for life, remainder to a group including me, with a power in the trustee to invade the corpus of the trust for the benefit of my mother in the event the life interest becomes inadequate for her comfort and support. My father has insisted on choosing a conflict-tainted trustee, making the judgment that I am to be trusted not to pauperize my mother to enrich myself. These situations are especially dangerous when the trust is given a controlling interest in a close corporation, and I am an officer of that firm. If he is well counseled, my father spells out broad authority for me as trustee, expressly trumping the default standards of the duty of loyalty. But when he neglects that step, contractarian analysis encourages us to look at the real nature of the trust deal, that is, what he and I understood, or what we would have understood about the purposes of the trust and the standard for my trusteeship. The standard is not the same as when my father places a portfolio of fungible financial assets in trust with Wells Fargo or Northern Trust.

\section{E. Trustee Insolvency}

I turn from the strengths of the contractarian analysis of the trust in accounting for trust fiduciary law to the weak point of contractarian analysis: the law of trustee insolvency, which governs the rights of outsiders to the trust deal. The handling of trustee insolvency is the feature of the modern trust that resonates most strongly in the property tradition. The Restatement version of the rule is that, "[a]lthough a trustee becomes insolvent or bankrupt, the beneficiary retains his interest in the subject matter of the trust if it can be identified ... [or traced], and is entitled thereto as against the general creditors of the trustee."215 Because trustee insolvency is not a common phenomenon, the subject is not much emphasized in the indigenous tradition of the law of trusts. ${ }^{216}$ It is striking, therefore, to discover how central this topic is in the comparative law literature. Europeans, who lack the trust, regard the law of

214. In re Rothko, 379 N.Y.S.2d 923, 936-37 (Sur. Ct. 1975), aff'd, 372 N.E.2d 291 (N.Y. 1977).

215. RESTATEMENT (SECOND) OF TRUSTS $\$ 12 \mathrm{cmt} . \mathrm{f}(1959)$.

216. For example, the leading law school course book, DUKEMINIER \& JOHANSON, supra note 184, gives it no mention. 
trustee insolvency as a defining element of the Anglo-American trust, ${ }^{217}$ and they find this feature of the trust perhaps the hardest to replicate in purely contractual arrangements.

The property rubric supplies the conventional explanation for the treatment of trustee insolvency in our law of trusts. The Restatement says: "The beneficiary of a trust has the beneficial interest in the trust property," whereas a creditor of the trustee "has merely a personal claim against the debtor."218 If you hold property for me under contract, it is said, I am your creditor, and thus I am at risk of your insolvency along with your other creditors. But that is only the starting point. Techniques of contract can approximate the trust outcome: Security interests suffice in some instances to protect the creditor's interest in an asset; the contract of agency sometimes leaves title in the beneficial owner while an agent manages; and the corporate form can be employed to defeat creditors. F.H. Lawson, explaining how the Europeans can approximate the trust, remarked: "What is a modern limited company ... but a device for limiting the access of creditors to a single fund? The interpolation of a fictitious person in the form of a company should not deceive anyone. $" 219$

An excellent example in our own law of a contractually based device that replicates the regime for protecting beneficiaries in the case of trustee insolvency is the life insurance company's separate account. Such accounts are authorized by statute in the main insurance states. The Connecticut legislation, for example, provides that: (1) the insurer may establish a separate account for a particular group of insurance or annuity policies; (2) the insurer may credit to the separate account the gains and losses on the assets allocated to that account "without regard to other income, gains or losses of the company"; but (3) "to the extent ... provided under the applicable contracts," that is, under the separate-account insurance or annuity policies, the separate-account assets "shall not be chargeable with liabilities arising out of any other business the company may conduct." ${ }^{, 220}$ The statute emphasizes that this arrangement sounds in contract, not trust. The separate-account assets are "owned by the

217. The 1984 Hague Convention on the Law Applicable to Trusts and Their Recognition (Hague Convention) exemplifies this perception. Article 11 provides that recognition of a trust implies "that personal creditors of the trustee shall have no recourse against the trust assets" and "that the trust assets shall not form part of the trustee's estate upon his insolvency or bankruptcy." 2 HAGUE CONFERENCE ON

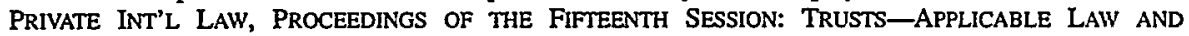
RECOGNITTON 361, 363-64 (1985) [hereinafter HAGUE CONFERENCE]. The Hague Convention is reprinted in 25 INT'L LEGAL MATERIALS 595 (1986).

218. RESTATEMENT (SECOND) OF TRUSTS $\S 12 \mathrm{cmt}$. a (1959).

219. LAWSON, supra note 10 , at 200.

220. CONN. GEN. STAT. ANN. § 38a-433(a) (West 1992); see id. § 38a-459 (authorizing such separate accounts for employee benefit plans); id. $\$ 38 \mathrm{a}-944$ (b) (reiterating that separate account is not chargeable with liabilities arising from insurer's general account or its other separate accounts). In Rohm \& Hass Co. v. Continental Assurance Co., 374 N.E.2d 727, 732-33 (Ill. App. Ct. 1978), the court sustained comparable Illinois legislation insulating insurance company separate accounts from unrelated liabilities of the insurer. 
company, and the company shall not be, nor hold itself out to be, a trustee with respect to such amounts."221

Whether, as a general matter, the protection against trustee insolvency that is characteristic of an ordinary trust fund could successfully be rested on such contract devices, it is certainly true that the ease of conceptualizing the trust fund as the beneficiaries' property has thus far largely spared us the need to try. I would be content to rest even the rule for trustee insolvency on the transactional law: Trust is a type of deal that prefers the trust beneficiaries over the personal creditors of the manager. But the traditional, property-based account is easy to reconcile with the contractarian account: Trust is a hybrid of contract and property, and acknowledging contractarian elements does not require disregarding property components whose convenience abides.

\section{LESSONS FROM NONTRUST LEGAL SYSTEMS}

I conclude this Article with the briefest glance in the direction of comparative law. I wish to leave my readers with three points that, although undoubted in the literature of comparative law, are sometimes unfamiliar to trust lawyers. First, the trust is a uniquely Anglo-American institution. The Continental legal tradition did not develop the trust. Second, when we ask how the Europeans function without the trust, we find that they achieve mostly by means of contract what the Anglo-American systems do through trust. Third, when a transaction with multistate dimensions causes one of these nontrust legal systems to confront the Anglo-American trust, the European courts analogize trust mostly to contract. The easy correspondence of trust and contract in European law is further indication of how close in function the trust lies to contract in our own law.

The relations between trust and nontrust jurisdictions were intensively studied in the preparations that led to the 1984 Hague Convention on the Law Applicable to Trusts and Their Recognition. ${ }^{222}$ The Hague Convention's

221. CONN. GEN. STAT. ANN. \$ 38a-433(a)(v) (West 1992). This negation of trust spares insurance companies from having to comply with the regulatory regime for trust companies.

222. The Hague Convention is mainly designed to facilitate recognition of the authority of a trustee who needs to act in a nontrust jurisdiction. The Convention avoids defining a trust, calling it the relationship that results "when assets have been placed under the control of a trustee." 2 HAGUE CONFERENCE, supra note 217, at 362 (Hague Convention Art. 2). The treaty isolates three characteristics of the trust that it treats as definitional: that "the assets constitute a separate trust fund and are not a part of the trustee's own estate"; that the trustee has legal title to the trust assets; and that the trustee has the power and duty to manage the assets "in accordance with the terms of the trust and the special duties imposed upon him by law." $2 \mathrm{id}$. This last element is what I have been calling the trust deal, as evidenced in the instrument and in the default regime. 
official report explains that "the laws of many countries simply do not have a category labelled 'trusts." 223 Instead,

the parties to a contract in civil law ... [may create] contractual obligations which bear a certain resemblance to trust arrangements. . . . [B]y a combination of [the Roman-derived contract types called] deposit and mandate some of the purposes may be achieved for which trusts are created; the resemblance is even stronger when the combination includes a contract for the benefit of a third party. $^{224}$

The Hague Convention report observes that the analogy from Anglo-American trust to Continental contract "is only partial" because the Continental arrangement is "of a purely contractual nature," and accordingly, "the depositary or mandatee is not given any proprietary rights with respect to the property."225 Although the Continental alternatives do not precisely replicate the trust, these "and similar contractual arrangements are quite successfully and extensively used in civil law systems." 226

When the Europeans confront a trust in judicial practice, they tend to treat it as a contract. The Hague Convention report discusses leading cases from Luxembourg (1971), France (1970), and Switzerland (1970), in which conflictof-laws issues about trust validity were resolved by characterizing the AngloAmerican trust in terms of the forum state's law of contractual obligations. ${ }^{227}$ For example, in Harrison v. Crédit Suisse, ${ }^{228}$ an Englishman attempted to create a trust in Zurich. The Swiss court reasoned: "As there exists in Swiss law no legal institution which corresponds in all its elements to the legal relationship created by the ... [attempted trust], it is necessary to examine which legal institutions of Swiss law ... [ [have] the closest resemblance.""229 Applying this method, the court determined that the trust had "certain elements of a contract of mandate, of a fiduciary transfer of property, of donation and of a contract for the benefit of a third party."230 The Hague Report concludes: "[T]he mainstream in the civil law characterization of the trust . . .

223. Adair Dyer \& Hans van Loon, Report on Trusts and Analogous Institutions, in 2 HAGUE CONFERENCE, supra note 217 , at 10,11 . The Report contains an extensive bibliography that collects much of the comparative law writing about the trust. Id. at 103-08.

224. Id. at 36.

225. Id.

226. Id.

227. Id. at 78-80. The Luxembourg case involved "a trust indenture for an issue of Eurobonds"; the court "characterized the Trust Indenture as a contract, in this case a contract of mandate," but concluded that "the trust did not stand up under the applicable law." Id. at 79.

228. Judgment of Jan. 29, 1970, ATF II, 96 Entscheidungen des Schweizerischen Bundesgerichtes 79 (Switz.).

229. Id. at 88 .

230. Id. 
emphasizes its flexibility and sees it as a contract-like institution . ..."231 In Europe, contract does the work of trust. ${ }^{232}$

I do not mean to imply that the Europeans function as well without the trust as they would with it. They do not. No European legal system has a planning tool for multigenerational wealth transfer that can rival a welldesigned Anglo-American estate plan, which combines the managerial strengths of the trust with the flexibility that our property law permits through future interests and powers of appointment.

\section{CONCLUSION}

In articulating the contractarian vision of the trust, it has been reassuring to find powerful support in quite diverse literatures. The historical work of Maitland points squarely to the contractarian account. We find the contractarian account implied in the doctrinal writing of Harlan Fiske Stone and Powell, the writers who refuted Scott; in the modern law-and-economics literature, notably Easterbrook and Fischel; and in comparative law.

I said at the outset of this Article that it was not my wish to fold the law of trusts into the law of contracts. Maitland was surely right to speak of the trust as perhaps "the most distinctive achievement" legal tradition. The trust straddles our categories of property and contract, because it embodies a contract about how property is to be deployed. What is special about the trust is the deal that subjects that property to the trust management regime.

My purpose in emphasizing the contractarian basis of the trust is to account for the trust more accurately, and, at the margin, to improve some mistaken results that the law reaches when contract notions are too subordinated. The conventional account of the trust that we find in the second Restatement and in the treatises simply does not give due weight to the bedrock elements of contractarian principle that inform the norms of trust law, namely, consensual formation and consensual terms. Trusts are deals.

231. Dyer \& van Loon, supra note 224 , at 81 .

232. This, too, is an insight that traces squarely to Maitland. He paused in the lectures on Equity to reflect on the uniqueness of the trust, which he thought was "perhaps . . . the most distinctive achievement of English lawyers. It seems to us almost essential to civilization, and yet there is nothing quite like it in foreign law." MAITLAND, supra note 7, at 23. The want of trust, Maitland said, seems to the English lawyer "a big hole" in Continental law. Id. The Europeans reply

that, instead of a big hole, civil law offers a bouquet of institutions which either alone or in combination fulfil most if not all of the functions of a trust. By instituting an independent juristic entity (a corporation or foundation), by setting up a contractual network of relationships, by transferring proprietary rights, by certain testamentary dispositions, and, most often, by a combination of two or more of these legal devices, it is possible to arrive at results which are very similar to those which common law systems have achieved through the trust.

Id. (cited in Dyer \& van Loon, supra note 223, at 40).

233. MAITLAND, supra note 7 , at 23. 


\section{APPENDIX: THE DECLARATION OF TRUST}

The text of this Article is devoted to the three-party trust relationship, in which the owner of the property (settlor) transfers it to a separate trustee for the benefit of the beneficiary. There is, however, another mode of creating an express trust that dispenses with the third-party trustee, the so-called declaration of trust. The settlor declares that he or she now holds the property as trustee for the beneficiary. ${ }^{234}$ The settlor remains the legal owner, but the declaration is treated as having transferred the beneficial interest to the beneficiary. "[F]or the last hundred years," Scott wrote, "it has been held that a trust may be created by a gratuitous declaration of trust." Enforcing such a trust shows that "the courts regard the transaction as a transfer of a beneficial interest rather than as the creation of an obligation." 235

Scott is correct that the declaration of trust cannot be squared with the contractarian account of the trust, which finds the basis of the trust obligation in the trustee's promise to the settlor to hold the trust assets for the benefit of the beneficiary. In the declaration-of-trust setting, the settlor is also the trustee and cannot contract with himself or herself. There is no trust deal, even though there is a valid trust. Accordingly, as was said at the outset of this Article, our law now permits trust obligations to arise apart from contract, when the settlor imposes those obligations upon himself or herself without making use of an intermediary. Because this arrangement does not achieve what most modern transferors want from a trust, namely, the management services of the thirdparty trustee, we would expect it to be little used.

When we observe how the declaration of trust is actually employed, we find that it usually results in one of three outcomes:

(1) The declaration functions as a nonprobate will that produces a onetime wealth transfer upon the death of the transferor, with no continuing trust relationship.

(2) The declaration functions as a curative doctrine to excuse noncompliance with the delivery requirement of the law of gifts, again producing a completed transfer with no continuing trust relationship.

(3) The declaration ripens on the transferor's death into a conventional three-party trust fully consonant with the contractarian model advanced in this Article.

In short, most usages of the declaration of trust are either nontrusts or way stations to real third-party-trustee trusts.

234. "A trust may be created by ... a declaration by the owner of property that he holds it as trustee for another person . ..." RESTATEMENT (SECOND) OF TRUSTS $\$ 17$ (a) (1959).

235. Scott, Rights, supra note 102, at 270 (citing Ex parte Pye, 18 Ves. 140, 34 Eng. Rep. 271 (Ch. 1811), discussed in Gregory S. Alexander, The Transformation of Trusts as a Legal Category, 1800-1914, 5 LAW \& HIST. REV. 303, 327-32 (1987)). 


\section{A. The Declaration of Trust as Nonprobate Will}

The best-known usage that passes under the name of the declaration of trust is the Dacey ${ }^{236}$ (or Farkas ${ }^{237}$ ) trust, which is simply a form of words used to achieve a nonprobate transfer on death. The Dacey trust is a will substitute, a nonprobate will, ${ }^{238}$ and heavily promoted as such. ${ }^{239}$ The purported settlor creates a revocable trust, declaring herself trustee for herself as beneficiary for life, with remainders to the persons who are in function the devisees. During the settlor's lifetime his or her dominion over the property-that is, over the nominal trust assets-remains total. On the settlor's death, if the settlor has left the arrangement unrevoked, it functions to transfer the property to the nominal remainder beneficiaries outside of probate (hence Dacey's jubilant book title, How to Avoid Probate $^{240}$ ). These remainderpersons had during the settlor's lifetime precisely that bare expectancy that characterizes the interest of a devisee under the will of a living testator.

Pressured by popular discontent with probate, American law resolved to allow the nonprobate will, and to allow the transferor to manipulate the language of trust to achieve it, but analytically the nonprobate will effected by means of the declaration of trust should not be confused with the trust. The settlor/trustee operating a Dacey trust owes no enforceable fiduciary duties to the nominal beneficiaries during the lifetime of the settlor/trustee. ${ }^{241}$ On his death, the so-called trust terminates, and the beneficiaries take the property outright. The trust label is simply being borrowed to legitimate probate avoidance.

\section{B. The Declaration of Trust as Curative for Failed Inter Vivos Gift}

We also find the declaration of trust employed as a curative device for failed inter vivos gifts, although such cases are relatively uncommon. The

236. NORMAN F. DACEY, HOW TO AvOID PROBATE (1965). On the popular success of Dacey's book, SEe DUKEMINIER \& JOHANSON, supra note 184 , at 352-53.

237. Farkas v. Williams, 125 N.E.2d 600 (Ill. 1955), is the leading case sustaining such a trust against the contention that, because it functions as a will but lacks Wills Act formality, it is void for violation of the Wills Act.

238. On the concept, see John H. Langbein, The Nonprobate Revolution and The Future of the Law of Succession, 97 HARV. L. REV. 1108, 1140-41 (1984).

239. Financial intermediaries competing against each other to sell investment products have promoted the declaration of trust. The Minneapolis-based mutual fund organization, Investor's Diversified Services, now a subsidiary of American Express, devised the form of declaration contested in Farkas. Norman Dacey was a mutual fund salesman who claimed to be "free[ing] Americans from the bondage of the iniquitous probate system." DACEY, supra note 236 , back cover.

240. DACEY, supra note 236.

241. See Langbein, supra note 238, at 1126-29 (explaining why Farkas trust fails its own purported "present interest" test). 
intending donor neglected to comply with the delivery requirement ${ }^{242}$ and is now unable to deliver, usually because the donor has since died. ${ }^{243}$ Delivery is a formality meant to distinguish between the case in which the transferor was serious about his donative purpose, and the case in which he was babbling idle chatter. When the court treats such a transferor as having uttered a declaration of trust, the transfer is enforced without the transferor having delivered the property. In such a case, the declaration of trust functions to dispense with the delivery requirement of the law of gifts, hence to evade the rule that our law does not enforce a mere promise to make a gift.

Using the declaration of trust to dispense with gift-law formality reminds us of Dacey's use of the declaration of trust to evade compliance with Wills Act formality. In each instance the declaration-of-trust label legitimates a oneshot transfer, as opposed to the long-duration regime of divided management and enjoyment that characterizes the genuine trust. The delivery-excusing gift effected under the declaration-of-trust label is a remedial device applied to cure a botched gift. Call something a declaration of trust, and the asset does not pass with the donor's estate, but is treated as having been the subject of a valid inter vivos gift to the donee. We can understand why our law might wish to have a curative device for failure of delivery when the gift was clearly intended, although we may lament that the measure takes the form of a fictional declaration of trust rather than a candid harmless error doctrine. ${ }^{244}$ The willingness of some courts to stretch the trust label to rescue imperiled gifts ought not to be confused with the work of the modern managerial trust.

\section{The Declaration of Trust as Conduit to Three-Party Trust}

There is one script under which the declaration of trust ripens into a conventional three-party trust, with a separate trustee managing the trust assets. The settlor sets up a Dacey-type revocable declaration of trust, a nonprobate will, but the instrument imposes a true trust on the remainder beneficiaries after the settlor's death. The terms provide for a successor trustee to be appointed at the settlor's death, to hold and manage the property for the benefit of the remainderpersons. This successor trustee is functionally indistinguishable from a testamentary trustee appointed under the will of a decedent, which is one of the classical modes of creating a conventional three-party trust relationship. When the successor trustee qualifies under the instrument (just as when the probate court appoints a testamentary trustee under a will), the threeparty trust relationship (settlor, trustee, beneficiary) falls into place, with all the attributes of contractarian trusteeship that would arise in a conventional trust

242. Discussed supra text accompanying note 30 .

243. Cases are reviewed in Love, supra note 96.

244. Contrast the harmless error doctrine now in place for Wills Act execution errors. UNIF. PROBATE CODE $\$ 2-503,8$ U.L.A. 109 (1990). 
agreement between living settlor and third-party trustee. I have explained in the body of this Article why testamentary trusts are contractarian despite the settlor's death. ${ }^{245}$ Like the testamentary trustee, the successor trustee decides whether to accept the trust on the terms contained in the instrument and in the background default law of trusts. Although this designated successor trustee, like a designated executor, has no one to contract with, trust law solves this problem by saying that the trust devolves upon the court, ${ }^{246}$ which places the court in the decedent's shoes for purposes of engaging the trustee.

To summarize: The two main uses of the declaration of trust are remote from the function of the modern trust. Sometimes the self-declared trust is a way station to the creation of a conventional, contractarian, three-party trust, when a successor trustee replaces the settlor/trustee. More commonly, in the Dacey version, the declaration of trust functions as a nontrust, borrowing the trust label to legitimate the nonprobate will, but not evidencing that relationship of divided management and enjoyment of trust property that is the hallmark of the modern trust.

245. See supra text accompanying notes 54-56.

246. RESTATEMENT (SECOND) OF TRUSTS $\S \S 33,104 \mathrm{cmt} . \mathrm{b}, 105 \mathrm{cmt}$. b (1959). The general rule is that equity will not allow a trust to fail for want of a trustee, and accordingly, the court will appoint a successor trustee if the original trustee dies or resigns, and the trust instrument has not made adequate provision for a successor trustee. See id. $\$ 101$ ("[T]rust will not fail when the person designated as trustee ceases for any reason to be trustee."). Likewise, the court will appoint a trustee to serve under a testamentary trust when the will neglects to designate someone who survives. But judicial appointment still presupposes consensual trusteeship - the person appointed must be willing to serve. The court has the power to appoint a trustee, but not to compel someone to accept. Imagine a trust with particularly unattractive terms, e.g., "my trustee shall be strictly liable for any decline in the value of the assets of the trust, without regard to fault." No one would accept the trust, and the court would either allow it to fail for want of a trustee despite Restatement $\S 101$, or else apply the doctrine of administrative deviation, discussed supra note 134 , to strike the offending term on a finding that the settlor would have preferred the trust without the term rather than have the trust fail. 


$$
\text { . }
$$

